\title{
NATURE AND FUNCTIONS OF COVER FOR RIVERINE FISH.
}

\section{S. ALLOUCHE}

UMR CNRS 5023 Ecologie des Hydrosystèmes Fluviaux, Université Cl. Bernard Lyon 1, F-69622 VILLEURBANNE Cedex, France. E-mail : sallouch@pop.univ-lyon1.fr

\begin{abstract}
This review attempts to assess the nature and the role of cover for riverine fish assemblages. Although early identified as a key factor for fish distribution, especially for salmonids, cover (i.e. woody debris, undercut banks, boulders, turbidity...) still remains the variable least considered in the studies of fish habitat relationships. This is mainly due to the diversity of ecological functions of cover structures in fish assemblages. Cover structures are structuring components of fish habitat and contribute to the biological productivity of streams. But, at the individual scale, cover fulfils three main functions: protection against predators, visual isolation reducing competition, and hydraulic shelter. In fact, the use of cover by fish results from a trade-off between the costs and the benefits associated with its use. Although the relationships between fish and cover appear extremely complex and context-specific, a growing body of evidence highlights the potential role of cover for management purposes.
\end{abstract}

Key-words : cover, shelter, riverine fish, fish habitat.

\section{NATURE ET FONCTIONS DU COUVERT POUR LES POISSONS LOTIQUES.}

\section{RÉSUMÉ}

Cet article décrit la typologie ainsi que les fonctions du couvert pour les poissons lotiques. Identifié très tôt comme un facteur explicatif de la distribution des poissons, principalement chez les salmonidés, le couvert (i.e. débris ligneux, sous-berges, blocs, turbidité...) demeure néanmoins la variable la moins considérée dans l'étude des relations habitat-poissons. Ceci s'explique notamment par les fonctions écologiques très diverses que le couvert remplit vis-à-vis des assemblages piscicoles. Les structures pourvoyeuses de couvert sont des agents structurants de l'habitat piscicole et contribuent à la productivité biologique des cours d'eau. Au niveau du microhabitat du poisson, le couvert remplit trois fonctions majeures : anti-prédation, isolation visuelle limitant la compétition, et abri hydraulique. En fait, l'utilisation du couvert par les poissons résulte d'un compromis entre les coûts et les bénéfices associés d'où l'extrême complexité de cette relation qui semble plutôt spécifique à un contexte donné. Malgré les difficultés d'extrapolation, de nombreux travaux mettent en évidence la signification écologique ainsi que l'utilisation potentielle du couvert pour une gestion optimale des ressources piscicoles.

Mots-clés : couvert, abri, poissons lotiques, habitat piscicole. 


\section{INTRODUCTION}

At all the levels of their organization, riverine fish assemblages depend on physical characteristics of habitat. Species richness increases with watershed size (GUÉGAN et al., 1998) and at the local scale with habitat diversity (GORMAN and KARR, 1978; SCHLOSSER, 1982, 1985, 1987). Numerous studies, mainly dealing with the association of upland stream salmonid assemblages with woody debris, revealed the importance of cover as a key factor governing fish distribution (BOUSSU, 1954; GRANDMOTTET, 1983; ANGERMEIER and KARR, 1984). Cover, at the scale of fish microhabitat, fulfils three main functions for individuals: protection against predation, visual isolation reducing competition, and hydraulic shelter. Although field studies often infer the underlying mechanisms that link fish with cover, it turns out that cover structures (e.g. woody debris, undercut banks, macrophytes...) are involved in the control of fish assemblages from upland streams to large rivers (DOLLOFF, 1986; THÉVENET, 1998). Despite the large amount of research that has been conducted, the real impact of cover on population dynamics and biodiversity remains poorly understood.

Numerous engineering works combined with the growing expanse of human understructures have caused strong dysfunctioning of temperate streams (GURNELL et al., 1995). Alteration of hydrologic and thermal regimes, degradation of water quality, clearance of riparian ecotones, and removal of instream cover have all contributed to the degradation of fish habitat and the decline of species (MAITLAND, 1995). Stream restoration is still rarely undertaken except in small salmonid streams (GORE and SHIELDS, 1995) and usually attempts to recreate pool-riffle patterns, to provide cover for fish, and to improve spawning gravel areas (SWALES and O'HARA, 1980; COWX et al., 1986; GORE and SHIELDS, 1995). However, as early as 1939, ELTON in his "On the Nature of Cover » expressed the urgent need to study extensively the complex nature of cover for animal communities because of this connection with schemes of wildlife preservation and restoration. In the last decade, some research has been conducted on lowland streams and large rivers (SLANEY et al., 1994; GORE and SHIELDS, 1995; THÉVENET, 1998; CROOK and ROBERTSON, 1999), which has then set the stage for a better understanding of the relationships between riverine fish and cover as prerequisites to fisheries management and predictive modelling.

This review is divided into six sections and is concerned with the description of physical structures or specific conditions identified by the literature as cover and with the role of this cover for riverine fishes. The first section defines cover, gives a typology of cover, and techniques for the assessment of cover and associated biological variables. The next sections consider the indirect impact of cover structures in diversifying fish habitat (section 2) and contributing to stream biological productivity (section 3). The fourth section reviews field studies dealing with the effect of cover structures at the population level. The fifth section identifies the functional basis of this relationship, mainly at the individual scale. This section describes the functions of cover relative to biotic interactions amongst fish (predation, competition, foraging) and hydraulic conditions (normal, flood, drought) and then the role of cover during critical periods such as the spawning and the winter seasons. This section ends with the functional significance of cover use in stream-dwelling fish as a dynamic trade-off among costs and benefits associated with the use of cover. The last section highlights the potential role of cover in lowland streams and management perspectives.

\section{DESCRIPTION OF COVER AND METHODOLOGY}

\section{Cover definition and typology}

Although cover is generally considered in the ichthyological literature as a habitat variable (FAUSCH and WHITE, 1981; BOVEE, 1982; GRANDMOTTET, 1983; HEGGENES 
and TRAAEN, 1988) it is probably the least well defined because of major difficulties to quantify it, evaluate its scale of action on fish, but especially to unambiguously ascribe to it one function for the fish, mainly in descriptive field studies. It is generally intimately associated with the concepts of habitat structure, habitat complexity or heterogeneity, as well as with the terms « shelter " and « refuge ". Sensu lato, cover is a generic concept without spatial restriction, including instream, overhanging or riparian structures, but also a specific condition that provides shelter from predators, competitors, or adverse abiotic conditions (swift currents, bright sunlight, extreme temperatures), as well as foraging and spawning sites. Sensu stricto, cover is an element perceived at the scale of fish microhabitat and that fulfils three main functions for fish: antipredation, visual isolation that decreases competitive interactions, and hydraulic shelter (FAUSCH, 1993). Thus, the term cover can be applied to substratum crevices and boulders, undercut banks, woody debris, algae, submerged and riparian vegetation, shading, water depth heterogeneity, water turbulence and turbidity, and also artificial structures (Table I and references therein). Water depth heterogeneity, surface turbulence, and turbidity that are in fact inherent conditions of lotic systems have a major although largely undocumented role. Alone they may fulfil the cover requirements of fish and thus cause equivocal results in attempts to link fish density and instream or overhanging structures.

Table I

Typology of physical structures and specific conditions considered as cover for riverine fish, with some illustrative references.

\section{Tableau I}

Typologie des structures physiques et des conditions spécifiques pourvoyeuses de couvert pour les poissons d'eau courante ainsi que quelques références illustratives.

\begin{tabular}{ll}
\hline \multicolumn{1}{c}{ COVER TYPOLOGY } & \multicolumn{1}{c}{ REFERENCES } \\
\hline $\begin{array}{l}\text { Substratum (crevices, } \\
\text { cobble, boulders) }\end{array}$ & $\begin{array}{l}\text { FAUSCH, 1984; BJORNN and REISER, 1991; GRIFFITH and } \\
\text { SMITH, 1993; STREUBEL and GRIFFITH, 1993; SHULER et al., } \\
\text { 1994 }\end{array}$ \\
\hline Undercut banks & BOUSSU, 1954; BRUSVEN et al., 1986; FRAGNOUD, 1987; LIM \\
et al., 1993
\end{tabular}


From upstream to downstream of the fluvial continuum, there is a gradual change in cover types and in the main functions fulfilled by cover. Upstream where salmonids dominate, rocky structures, water turbulence, canopy, and instream woody debris constitute the main cover elements and principally temper the effects of abiotic disturbances and terrestrial predation, both avian and mammalian (Figure 1). Boulders create a major fish habitat in high-gradient streams by providing pools with increased water depth and surface turbulence that may be the only cover available. The canopy is probably one of the most important cover features affecting fish distribution since its regulates stream temperature, provides shelter during floods, supplies nutrients and terrestrial invertebrates as fish food, and instream cover for fish (SCHIEMER et al., 1995). In midreach locations where rheophilous cyprinids dominate, all cover types become equally represented and temper the effects of abiotic disturbances and both terrestrial and aquatic predation (Figure 1). Downstream where lentic cyprinids dominate, turbidity, water depth and rooted macrophytes fulfil the cover requirements of fish and principally temper the effects of aquatic predation (Figure 1). This conceptual framework is very general and requires much fitting according to the geographic, climatic and human contexts.

TYPOLOGICAL CHANGES
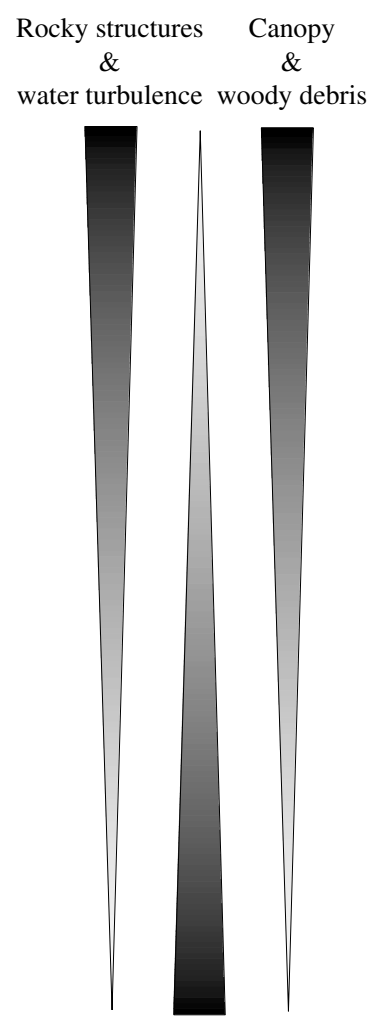

Turbidity, water depth \& macrophytes

\section{FUNCTIONAL CHANGES}

$\begin{array}{cl}\text { Abiotic } & \text { Terrestrial } \\ \text { disturbances } & \text { predation }\end{array}$
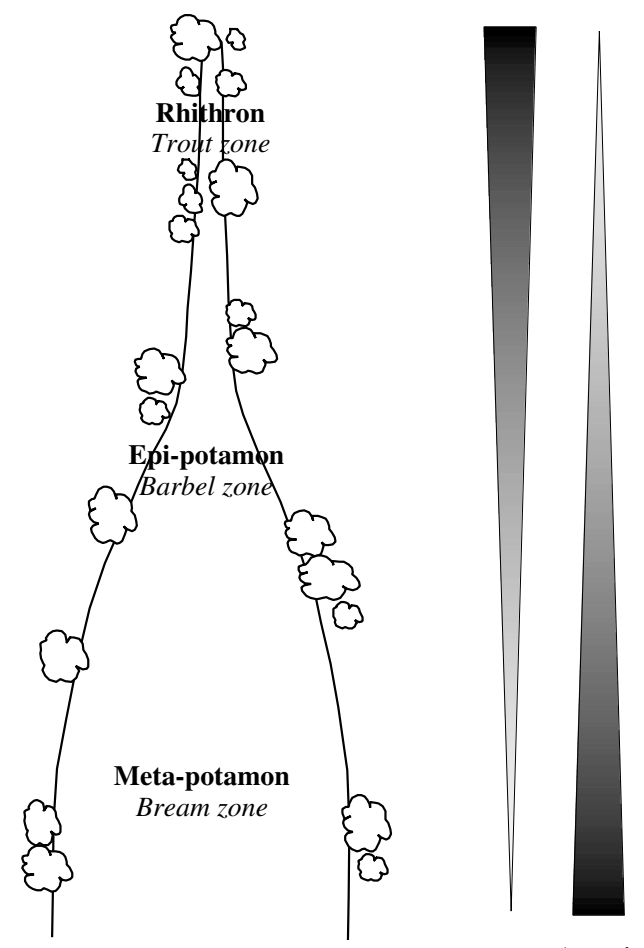

Aquatic predation

Figure 1

Typological and functional changes of cover from headwaters to lower mainstreams (stream fish zonations of HUET (1959) in italics, and ILLIES and BOTOSANEANU (1963)).

\section{Figure 1}

Evolution typologique et fonctionnelle du couvert de l'amont vers l'aval du continuum fluvial (zonations piscicoles de HUET (1959) en italique, et ILLIES et BOTOSANEANU (1963)). 


\section{Cover assessment techniques}

Besides catchment variables (geomorphology, hydrology, or chemistry), cover has been identified as an important site attribute having significant correlations with salmonid populations (FAUSCH et al., 1988; SHIRVELL, 1989) but little effort has been made so far to integrate cover in existing models (BINNS and EISERMAN, 1979; BOVEE, 1982; FAUSCH et al., 1988; STONEMAN and JONES, 2000).

Assessment of cover is generally limited to some qualitative description of the structure present in the sampled area and to some quantitative information such as percent area covered and volume (STEVENSON and BAIN, 1999). More recently, an effort has been made to produce more objective measurement methods and distributions of data compatible with other hydraulic variables (i.e. continuous variables) used in traditional models (KINSOLVING and BAIN, 1990). By counting the surfaces of submerged objects in a vertical plane, these authors quantified three cover parameters as follows: cover density (non-zero planes), complexity (mean number of surfaces counted) and heterogeneity (variance in surface counts). The most widespread approach is to use field heterogeneity measures that describe the variations of some variables between adjacent points within the cover structures (THÉVENET, 1998). For " soft » structures like macrophytes, the simplest is to express the variations of height at successive points to produce a topographic complexity index. For « hard " structures like boulders it is to lay a chain from bank to bank across the substratum and the structures and to quantify the deviation from a flat bottom (MATTHEWS, 1998). Another approach to quantify heterogeneity is to use formulas stemming from " information theory » and quantitatively describe the proportions of different cover classes per variable (GORMAN and KARR, 1978). Globally, such complex categorizations allow a better understanding of the intrinsic characteristics (e.g. structural complexity, cavity space) explaining the presence or absence of fish within a cover structure (LEHTINEN et al., 1997; MONZYK et al., 1997) but the value of more complex schemes appears questionable. In fact, THÉVENET (1998) defined 10 variables to describe the structural complexity of coarse woody debris (CWD) but only the percentage area covered by CWD, probably acting as a surrogate of complexity, explained the density and diversity of fish in the zone investigated.

Some authors have suggested that fish are mainly attracted by associated features, such as shade or hydraulic diversity, rather than physical attributes of cover (SHIRVELL, 1990). Little research has been completed on this aspect because it is time-consuming in the field and difficult to perform practically. Fish attraction for cover is largely influenced by the architectural arrangement of cover structure (i.e. complexity, cavity space...) and also the diversity of other associated habitat features generated by the structure (hydraulic heterogeneity, light intensity...) (JOHNSON, 1993; LEHTINEN et al., 1997; MONZYK et al., 1997; THÉVENET, 1998). For example, brown madtoms (Noturus phaeus) used more frequently woody debris having greater cavity space and structural complexity, suspended leaves, and located beneath undercut banks or next to areas of high flow (MONZYK et al., 1997). One can consider that these two kinds of intrinsic characteristics may act in synergy in the process of cover selection, and examination of these physical variables is really needed to optimize the design and location criteria of cover structures.

As cover management practices are now the basis for the conservation of either target species or assemblages, it becomes essential to standardize measurement techniques. This will permit real comparisons between studies and the best evaluation of the causes of failure or success of some restoration works. However, a detailed review of techniques relating to cover is beyond the scope of the present paper (see e.g. BAIN and STEVENSON, 1999). Moreover, it seems essential to take account of variables describing cover in habitat models as they may contribute both to the theoretical understanding of the fundamental processes and to the prediction of changes in standing crop following cover enhancement practices. 


\section{Assessment of biological attributes}

Most of the field assessments of cover use by riverine fish have relied on measurements of fish abundance and species number and an assortment of cover features in a stream reach. The most widespread approach is to perform a population inventory within the sampled zone (cover structure, mesohabitat, or reach) by successive pass removal electrofishing after confining the sampled zone with blocking nets (but see THÉVENET, 1998 for an open sampling technique). Rarely were abundances of benthic and drifting invertebrates jointly undertaken (ANGERMEIER and KARR, 1984; ELLIOT, 1986). Since the measure of fish density cannot account for the significance of cover for population dynamics, at least for territorial species such as salmonids, some authors have also marked individuals and used Capture-Marking-Recapture (CMR) for addressing the demographic mechanisms (growth, survival, or immigration) responsible for changes in population abundance or biomass with changes in cover structures (GOWAN and FAUSCH, 1996; QUINN and PETERSON, 1996; HARVEY 1998). In many instances, visual observation from the banks (BACHMAN, 1984) and by snorkelling (FAUSCH and WHITE, 1981; GRIFFITH and SMITH, 1993), or radiotelemetry (TODD and RABENI, 1989; YOUNG, 1995; ALLOUCHE et al., 1999; HARVEY et al., 1999) has allowed either counts or behavioural records.

These different kinds of observation methods may have some sampling bias. At the reach scale electrofishing is well adapted when using blocking nets but at the scale of the cover structure it may overestimate cover use because of fright bias (e.g. refuging behaviour of BOVEE, 1982). To overcome this bias, a sampling technique using preinstalled anodes (BAIN et al., 1985) that surprise the fish within the cover habitat could be more efficient. Direct underwater observation may underestimate the use of cover in shallow, turbid, or fast-flowing water, in highly structured instream cover, and at low water temperature because fish are difficult to see (HEGGENES et al., 1990). Finally, despite its significant costs radiotelemetry provides a finer degree of spatial and temporal resolution and thus allows to determine the pattern of activity in relation with cover features and to quantify their function (ALLOUCHE et al., 1999). However, it is noteworthy that telemetry is still not possible for small fishes (LUCAS and BARAS, 2000).

\section{EFFECTS OF COVER STRUCTURES ON HABITAT FEATURES}

Some of the elements providing cover (e.g. boulders, CWD) are also structuring agents of fish habitat at various spatio-temporal scales. These elements provide heterogeneity of light intensities and hydraulic variables among microhabitats and within mesohabitat units but can also be involved in the distribution pattern of mesohabitat units (SHIELDS JR and SMITH, 1992; ABBE and MONTGOMERY, 1996; GIPPEL et al., 1996). For example, woody debris may contribute to geomorphic processes such as step-pool profile formation, waterfall formation, initiation of vegetated islets on gravel bars, or backwater formation (BILBY and WARD, 1989; ROBISON and BESCHTA, 1990; GURNELL et al., 1995; RICHMOND and FAUSCH, 1995). By increasing the diversity of the stream bed, trapping gravel, and creating shallow gravel bars, woody debris or stream enhancement structures are used to increase spawning habitat for salmonids (HOUSE and BOEHNE, 1985). Although the effects of woody debris decrease as one goes downstream in the river network (HARMON et al., 1986; INOUE and NAKANO, 1998; PIEGAY et al., 2000), GURNELL et al. (1995) suggested that their presence induces increased physical habitat diversity in all sizes of streams. Finally, macrophyte cover as a "soft "structure is also known to structure physical habitat by decreasing current velocity and incident light in a seasonal cycle and to affect fish assemblages in various ways (HAURY and BAGLINIÈRE, 1996). 


\section{EFFECTS OF COVER STRUCTURES ON BIOLOGICAL PRODUCTIVITY}

Cover structures may both indirectly and directly contribute to the nutrient budget and trophic dynamics of streams by increasing the trapping of allochthonous material, enhancing primary and secondary production, and increasing the abundance and diversity of invertebrates.

First, since allochthonous input is the greatest energy source for food webs in most streams (HILDREW, 1992), cover structures indirectly influence productivity by playing a significant role as retention devices, allowing the processing of organic matter and nutrients, and controlling the rate of transport of material downstream (ANGERMEIER and KARR, 1984; GURNELL et al., 1995; HAURY and BAGLINIĖRE, 1996). Second, communities of algae, plants, and invertebrates inhabiting and decomposing organic matter from cover structures are major food items for many fishes (DUDLEY and ANDERSON, 1982; BENKE et al., 1985; SUREN and WINTERBOURN, 1992; HAURY and BAGLINIĖRE, 1996). The contribution of one type of structure to primary and secondary production depends on its overall abundance, quality as a substratum and location within the catchment (HARMON et al., 1986). For example, woody material itself has little nutritional value but the biofilms associated with the wood are most beneficial to macroinvertebrates (HAX and GOLLADAY, 1993).

In streams of all sizes, the abundance and diversity of invertebrates, a major source of food for many fishes, are strongly correlated to the degree of structural complexity of habitats (macrophyte beds, substratum or wood crevices) (O'CONNOR, 1991; DOUGLAS and LAKE, 1994; COGERINO et al., 1995; DOWNES et al., 1998). In lowland sand-bottom streams, woody debris support invertebrate production that is among the highest in lotic systems (SMOCK et al., 1989). Snags which represented only $4 \%$ of the total habitat surfaces provided $60 \%$ and $78 \%$ of the benthic and drifting invertebrate biomass, respectively, which made up $60 \%$ of the diet of three sunfish species (Lepomis) and pirate perch (Aphredoderus savanus) (BENKE et al., 1985). Invertebrates use cover structures as refuges from predation and adverse abiotic conditions but also as a feeding or a reproductive habitat. Some species directly ingest the surface of the structures, feed upon associated organisms (bacteria, fungi, algae and periphyton), or use it as an attachment site for filter feeding or emergence (DUDLEY and ANDERSON, 1982; HARMON et al., 1986; PHILLIPS and KILAMBI, 1994).

However, some types of cover can decrease stream productivity. This principally concerns the wooded riparian cover that dramatically affects primary production and organic matter inputs. In the heavily shaded sections of the upper and middle reaches of the river continuum this may reduce autochthonous matter production and consequently invertebrate and fish biomass. Clear-cut reaches due to logging practices in the United States had higher temperatures, more periphyton, benthos, and fish than buffered or oldgrowth reaches, as increased light reaching the stream stimulated production and extended the summer growing season (MURPHY et al., 1986). But these growth benefits are known to be rapidly offset by a reduction in the amount of critical overwintering instream cover and increasing fish mortality (JOHNSON et al., 1986).

\section{EFFECTS OF COVER STRUCTURES ON FISH POPULATIONS}

Many authors have demonstrated correlations between cover features and population abundance, biomass, survival, or diversity of fish assemblages based on field observations in coldwater streams (LEWIS, 1969; NIELSEN, 1986), warmwater streams (ANGERMEIER and KARR, 1984), and more recently in large rivers (LEHTINEN et al., 1997; THÉVENET, 1998). A lack of suitable cover habitat has been identified as a potentially important factor affecting overwinter population density (BJORNN, 1971; 
BUSTARD and NARVER, 1975; RIMMER et al., 1983) and recruitment or early survival of some salmonid species (MORTENSEN, 1977; QUINN and PETERSON, 1996). Some authors have also reported the importance of cover in lowering the dispersal patterns and the extent of habitat range of fish populations (LEWIS, 1969; BJORNN, 1971; APARICIO and DE SOSTOA, 1999; HARVEY et al., 1999; RONI and QUINN, 2001a) reinforcing the hypothesis that the degree of structuring of habitats influences movement rates (BAADE and FREDRICH, 1998).

Experimental field studies which manipulated cover features by removal or addition (treatment vs control sections) and measured changes in fish abundance or biomass (prevs post-treatment comparisons) confirm these empirical results. Most studies validate the relationship between cover abundance and fish density or biomass, principally of salmonid species (BOUSSU, 1954; SAUNDERS and SMITH, 1962; HOUSE and BOEHNE, 1985; DOLLOFF, 1986; ELLIOT, 1986; RILEY et al., 1992; LIM et al., 1993; RONI and QUINN, 2001b) but also of cyprinid species (SWALES and O'HARA, 1983; THÉVENET, 1998). But in contrast, BJORNN et al. (1991) and KEITH et al. (1998) found that the summer distribution of juvenile salmonids (Oncorhynchus kisutch, Salvelinus malma) was not or little affected by the presence of cover. In fact, comparisons between field studies are extremely difficult since they differ by numerous parameters: species and life-stages, cover types, stream characteristics, spatio-temporal scales, intensity of biotic interactions, and statistical reliability (BJORNN et al., 1991).

As a matter of fact, although cover management practices are widely used at the reach scale, whether cover addition really increases stream carrying capacity rather than simply redistributing the existing population remains controversial. Classical literature on marine and lentic systems suggests that artificial reefs redistribute, attract and aggregate fishes from surrounding areas due to behavioural preferences but do not increase overall production (BOHNSACK, 1989; LYNCH JR and JOHNSON, 1989; MORING and NICHOLSON, 1994; GROSSMAN et al., 1997). Recent works of GOWAN and FAUSCH (1996) (see also RILEY et al., 1992; RILEY and FAUSCH, 1995) using a demographic CMR method over an 8-yr study (= 4 generations for fish) greatly revived the controversy for streams. They revealed that within 2 years after installation, log drop structures caused significant increases in pool volume, depth, and cover, as well as increases in the abundance and biomass of adult trout (Salvelinus fontinalis, Salmo trutta, Oncorhynchus mykiss), but not juveniles. Furthermore, they reported that populations responded through immigration rather than in situ processes such as increased recruitment, survival or growth, but concluded that fish survival and biomass at the reach scale might have increased since immigrants left a less suitable habitat where they might have died and subordinate individuals could fill this less suitable habitat and increase their own survival.

More generally, some indirect evidence supporting increased production due to cover structures can be provided by demonstrating the existence of increased growth, one of the hypothesized production mechanisms directly linked with individual fitness. However, in most field studies where confounding factors are numerous, it has been found that the presence of cover has no (SAUNDERS and SMITH, 1962; FAUSCH and NORTHCOTE, 1992; FAUSCH et al., 1995; FLEBBE and DOLLOFF, 1995; GOWAN and FAUSCH, 1996; HARVEY, 1998) or even a negative effect (WILZBACH et al., 1986) on growth although increased growth rates are sometimes attributed to the presence of rootwad cover (NIELSEN, 1992) or riparian cover (VILA-GISPERT et al., 2000). Results obtained in laboratory experiments are also equivocal due to difficulties in defining working hypotheses and to methodological problems (e.g. SPALDING et al., 1995 and comments in COUTANT, 1996). Finally, aquaculture research reported few results with real benefits to growth, food conversion, and general health after rearing fish with overhead covers (WAGNER and BOSAKOWSKI, 1994). 
So far, the relationship between fish populations and cover is mainly based on North American studies where the role of woody debris is essential in geomorphic processes (SAUNDERS and SMITH, 1962; DOLLOFF, 1986; HOUSE and BOEHNE, 1986). More recently, results derived from other geographical regions where riparian forests have less effects on these processes have validated the role of CWD for fish abundance and diversity (LANGFORD and HAWKINS, 1997; INOUE and NAKANO, 1998; THÉVENET, 1998). It seems that even in systems where riparian corridor is sparse and instream woody debris are scarce, debris probably influence fish assemblage structure, diversity and abundance, but this remains largely undocumented (LEHTINEN et al., 1997).

\section{FUNCTIONAL ROLES OF COVER}

Fundamentally, the association of fish with cover depends on basic stimuli (taxes) which are instinctive orientation responses to physical structure, light or current. Experimental studies have demonstrated that selection of shelters may be initiated by negative phototaxis (MCCRIMMON and KWAIN, 1966; DEVORE and WHITE, 1978; HELFMAN, 1979), positive thigmotaxis (DEVORE and WHITE, 1978), and negative rheotaxis (HAINES and BUTLER, 1969). Generally, shade was the more important stimulus and cover structures providing the most complex association of stimuli (visual, tactile, rheotactic) were used preferentially (HAINES and BUTLER, 1969). Although less studied, some species may use instream cover as landmarks for orientation purposes. Using visual, chemical, and lateral line stimuli directly from cover or indirectly from water movements, fish may be able to construct cognitive maps of their habitat allowing them to orientate efficiently within their home range (CROOK and ROBERTSON, 1999). Some research works showed that learning of global or local habitat features like cover is important for the expression of various behaviours (territorial, refuge, foraging, predator and competitor avoidance...) (KIEFFER and COLGAN, 1992).

However, the association of fish with cover is a complex phenomenon involving numerous functions for riverine fish. The underlying mechanisms have been clearly demonstrated by behavioural experiments performed in aquaria and artificial streams. This section first presents the functions of cover relative to biotic interactions, hydraulic conditions and during critical periods such as the spawning and winter seasons. In fact, a given taxon may use cover structures for several or only one function and the relative magnitude of these functions greatly depends on life history traits and environmental conditions. This section will be concluded by analyzing costs and benefits associated with cover use by riverine fish.

\section{Biotic interactions}

\section{Predation}

Threat of predation plays a prominent role in habitat selection by fish and induces real demographic consequences affecting prey population dynamics and strong indirect ecological effects (POWER et al., 1985; FRASER and GILLIAM, 1992; LIMA, 1998). Assessments of the mortality caused by piscivores in lotic communities are always equivocal, mainly because they are underestimated. Although some studies reported high impact (ALEXANDER, 1979; WHITE and HARVEY, 2001), long-term effects of predation are generally considered limited (DRAULANS, 1988; MATTHEWS, 1998).

Piscivorous birds may be efficient predators in small streams whereas piscivorous fish may pose a more constant threat further downstream. As a consequence, fishes often show strong size-specific partitioning by depth (SCHLOSSER, 1982; HARVEY and STEWART, 1991), leading to the conceptual framework that in small streams $\left(1^{\text {st }}-3^{\text {rd }}\right.$ orders $)$ 
the highest risk of predation in shallow habitats is for large fish, due to non-gape limited predators (birds and mammals) whereas in deeper habitats it is for small fish from gapelimited, piscivorous fish (POWER, 1987; SCHLOSSER, 1987). Some laboratory and field experimental studies have clearly demonstrated that terrestrial predation risk from wading/diving animals is much higher for water-column species in shallow pools than in deep pools and added cover markedly increases their survival (HARVEY and STEWART, 1991; LONZARICH and QUINN, 1995; REINHARDT and HEALEY, 1997). Hence, beyond physical structures that provide shelter from predators, water depth heterogeneity constitutes an essential cover feature regulating predator-prey interactions.

Sheltering is a common antipredator tactic in fishes since the structural complexity of cover reduces the predator foraging success (CROWDER and COOPER, 1982; ROZAS and ODUM, 1988; EKLÖV, 1997; KATS and DILL, 1998). Several studies have shown that small fish taxa increased cover use in the presence of fish predators (WERNER et al., 1983b; HUNTINGFORD et al., 1988a; RAHEL and STEIN, 1988; BUGERT and BJORNN, 1991; BUGERT et al., 1991) and bird predators (HOLIERHOEK and POWER, 1995; REINHARDT and HEALEY, 1997) or remained in risky sites only if those sites were structurally complex (FRASER and CERRI, 1982). The underlying mechanisms of the reduction in predator foraging success included a limitation of manoeuvrability of predators, a reduction in visual contacts, and an increase in evasive abilities of prey (HELFMAN, 1981). Empirical data either suggested that a threshold level of cover density is necessary to reduce predator foraging success (SAVINO and STEIN, 1982; GOTCEITAS and COLGAN, 1989) or that predation rates are a linear decreasing function of cover complexity (CROWDER and COOPER, 1978; NELSON and BONSDORFF, 1990). Furthermore, empirical and theoretical studies have long suggested that intermediate structural complexity of cover maximizes predator feeding rates and in the long-term may stabilize predator-prey interactions by preventing prey extinction (CROWDER and COOPER, 1982; SAVINO and STEIN, 1982; but see MCNAIR, 1986). However, piscivores are differentially affected by varying degrees of cover complexity as a result of speciesspecific differences in predator efficiency and prey antipredator tactics (ANGERMEIER, 1992; EKLÖV and PERSSON, 1995). Ambush piscivores, like northern pike Esox lucius or bass Micropterus spp., that rely on cover to conceal themselves, may have high foraging success at relatively high cover density (HECK and CROWDER, 1991).

Several studies also suggested that fish can control their escape decision, which incurs costs (energy expenditure and lost opportunity to engage in other activities), through their proximity to cover. Flight initiation distance (i.e. between predator and prey) increases as distance to cover increases (MCLEAN and GODIN, 1989; DILL, 1990) or when cover density is low (GRANT and NOAKES, 1987). Additionally, FRASER (1983) noted that adult creek chub (Semotilus atromaculatus) aggregated near a shelter if this was the only one, but dispersed if multiple shelters were available. Thus, the occurrence of cover may play a considerable role in foraging-site selection and dispersal patterns at the scale of the activity area (BACHMAN, 1984).

In comparison with lentic environments, relatively little research has been carried out in streams but cover probably enhances prey fish persistence by reducing predator efficiency. In the field, the antipredator function of cover ( $v s$ foraging or hydraulic purposes) is often inferred rather than directly demonstrated (but see EVERETT and RUIZ, 1993; WHITE and HARVEY, 2001). Furthermore, an understanding of the emergent impact of multiple predators (aquatic vs terrestrial or searching vs sit-and-wait predators) on prey can provide insights for guiding fishery practices of cover structure management $(\mathrm{SIH}$ et al., 1998). For example, by avoiding fish predators that hunt beneath cover, prey fishes may become more vulnerable to avian predators as they move into open areas and vice-versa. 


\section{Competition}

Competition between/among species is actually accepted as a potential driving force that shapes fish assemblages and prevails in stable systems when resources become limited (MATTHEWS, 1998). In stream-dwelling salmonids, field observations and laboratory experiments suggest that selective segregation for cover use (i.e. innate cover preference resulting from natural selection) plays a major role in the coexistence of closely related species (CUNJAK and GREEN, 1983; DOLLOFF and REEVES, 1990). However, there is also experimental evidence on interactive segregation (i.e. by agonistic interactions) between salmonid species either for energetically profitable positions (e.g. hydraulic shelter adjacent to swift current) (FAUSCH, 1984), or for resting cover (CARON and BEAUGRAND, 1988; GREGORY and GRIFFITH, 1996). FAUSCH and WHITE (1981) showed that in a small stream with scarce resting cover, introduced brown trout (Salmo trutta) aggressively excluded indigenous brook trout (Salvelinus fontinalis) from cover. In a field analysis of habitat use in sympatry and allopatry, BARAN et al. (1995) revealed that brown trout displaced rainbow trout (Oncorhynchus mykiss) from preferred positions beneath undercut banks.

As early as 1958, KALLEBERG quantified the visual isolation function of substratum cover for territorial juvenile salmonids in summer since addition of large stones resulted in less aggressive behaviour, smaller sizes of territories, and allowed more individuals to exist in close proximity. There is also some inferential evidence supporting the importance of visual barriers provided by instream cover in increasing salmonid abundance (DOLLOFF, 1986; MESICK, 1988; MCMAHON and HARTMAN, 1989; BUGERT et al., 1991; FAUSCH, 1993). SUNDBAUM and NÄSLUND (1998) quantified the better condition maintained by juvenile brown trout in channels with instream cover because of reduced aggressive interactions and swimming activity. Recently, ARMSTRONG and GRIFFITHS (2001) found that sheltering behaviour of wild juvenile Atlantic salmon is density-dependent reinforcing the hypothesis that instream cover availability may be very important in salmonid nursery streams by increasing density-dependent growth and decreasing winter mortality (MORTENSEN, 1977).

Finally, some studies performed in lentic systems have demonstrated strong intraand interspecific competition in sheltered habitats. Under predation risk, sunfish juveniles were concentrated under macrophyte cover and thereby suffered increased competition for food (WERNER et al., 1983a; MITTELBACH, 1986). Moreover, shifts in competitive ability between juveniles of different species driven into refuges have been shown. For example, a growth advantage of roach (Rutilus rutilus) in open water was reversed to a growth advantage of perch (Perca fluviatilis) in cover habitat (PERSSON, 1993). Thus, structural complexity of cover can affect prey diversity by providing competitive refuges for certain species.

It appears that for highly territorial species or ambush piscivores, competition among individuals having the same cover requirements may eventually lead to the exclusion of one of the individuals through interference if cover is scarce. Individuals less able to defend cover sites may suffer increased predation and decreased growth. For non-territorial species like shoaling cyprinids, competition for cover probably rarely occurs whereas competition for food between small taxa restricted to cover may be conceptually an important mechanism regulating lotic fish assemblages. In spite of these few examples, the role of cover and associated complexity in either increasing or reducing competition in running waters has been rarely explored.

\section{Foraging}

It has already been pointed out here that cover structures can be hotspots of primary and secondary production as well as of macroinvertebrate diversity, thus providing rich 
feeding areas for fishes. Both in tropical and temperate streams, many herbivorous fishes (e.g. armoured catfish, stoneroller, rudd, roach, dace, nase, chub) directly eat attached algae from hard substrata and to a lesser extent macrophytes (LAMMENS and HOOGENBOEZEM, 1991; MATTHEWS, 1998). Certain taxa can control standing crops and patchiness of plant cover by their grazing activities and thus control the availability of shelter for numerous other taxa (POWER, 1983; MATTHEWS, 1998) as well as invertebrate standing crop, with strong indirect impacts on insectivores (FLECKER, 1992). Shade produced by instream cover is also used as camouflage by piscivorous fish that ambush their prey (HELFMAN, 1981). In the upper Mississippi River, most piscivorous fishes (walleye, largemouth bass, black crappie) were collected at snag sites (LEHTINEN et al., 1997). YOUNG (1995) observed that large brown trout occupied deep water habitats near the bank and close to cover and suggested that the ambush foraging strategy of these piscivorous fish may account for their use of cover.

Although the complexity of instream cover can increase foraging opportunities for insectivorous fishes through enhanced secondary production, the direct benefits of cover for fish depends on species, body size, and feeding mode. Overall, numerous studies have reported that structural complexity in macrophytes (DIEHL, 1988; SAVINO et al., 1992), woody debris (EVERETT and RUIZ, 1993), and substratum (POWER, 1992; BECHARA et al., 1993) may decrease the effectiveness of fish predation on macroinvertebrates. By impeding their visual field, shade may drastically limit the feeding efficiency of drift-feeders (WILZBACH et al., 1986; O'BRIEN and SHOWALTER, 1993) that may benefit far more from cover structures by taking positions directly downstream from these structures (NIELSEN, 1992). At a higher spatial scale, riparian cover may both greatly reduce autochthonous production of a stream reach thus negatively impacting fish growth, but also provide terrestrial invertebrates which may constitute a large part, at least seasonally, of the diets of some species (MASON and MACDONALD, 1982; COLLARES-PEREIRA et al., 1995; BRIDCUT, 2000; KAWAGUCHI and NAKANO, 2001).

\section{Hydraulics}

\section{Normal conditions}

In fishes, for sustaining positions, flowing water imposes energetic cost that varies with season and temperature and depends on their swimming capabilities (FACEY and GROSSMAN, 1990). Bioenergetic efficiency is affected by the availability of hydraulic shelter that does not need to be very large to affect local velocities, contrary to antipredator cover which needs sufficient structural complexity to be efficient. Heterogeneous substratum granulometry constitutes the most frequent hydraulic cover (e.g. BJORNN and REISER, 1991).

Beyond this purely energy-saving function, instream cover may create energetically efficient foraging sites for drift-feeders. In fact, the number of invertebrates drifting through the fast-flowing areas per unit of time is higher than in the slower, open areas (HILL and GROSSMAN, 1993). Hence, many fishes maintain sheltered positions from which they dart into adjacent swift current to capture drift items (BACHMAN, 1984; FAUSCH, 1984). After the placement of boulders in the Rio Grande River in summer, $65-71 \%$ of juvenile and adult brown trout were observed near boulders (SHULER et al., 1994). The authors suggested that by creating more feeding sites that are energetically favourable for trout during summer, boulders may indirectly enhance their body condition and thus overwinter survival. The energy-optimization utility of these foraging sites has been revealed by simple intake rate/growth maximization models which try to predict habitat selection by salmonids in experimental streams (FAUSCH, 1984) and in the field (HUGHES and DILL, 1990; HUGHES, 1992; GUENSCH et al., 2001). These models showed that individuals ranked positions according to their potential profit by combining hydraulic, drift and other biological parameters (detection distance of prey, presence of competitors). 


\section{Floods}

Floods are considered major events regulating fish assemblages mainly because of their beneficial ecological effects over time (habitat formation, allochthonous inputs, creation of nursery floodplain habitats, food web complexity...) (MATTHEWS, 1998). However, erosive floods may have immediate negative effects on fish assemblages by increasing downstream displacement, mortality of free-swimming fish, and destroying nests and eggs. Moreover, the destruction and the removal of cover structures may induce strong negative effects by lack of shelter from predators and depression of trophic resources (MATTHEWS, 1998). Although the behavioural tactics exhibited by fishes during floods have been less studied, the use of instream cover as hydraulic refuge has been shown and is known to temper these negative effects (BJORNN, 1971; BUSTARD and NARVER, 1975; CUNJAK and POWER, 1987; HEGGENES, 1988b; VALENTIN et al., 1994; but see HARVEY et al., 1999).

For instance, during simulated freshets, most coho salmon (Oncorhynchus kisutch) emigrated from experimental channels unless complex cover combining low velocity, shade, and structural complexity was available (MCMAHON and HARTMAN, 1989). Coarse rocky substratum constitutes an essential hydraulic refuge since sudden 4-100 times increased discharge in a small stream did not displace yearling brown trout as long as heterogeneous substratum provided micro-environments where flow was below critical velocity of fish (HEGGENES, 1988a). In contrast, strong reductions in juvenile and adult brown trout abundances, highly correlated with river gradient and instream cover, were observed after a severe flood in seven New Zealand rivers (JOWETT and RICHARDSON, 1989). Fish assemblages were more resistant to erosive floods in complex reaches with boulders and woody debris than in more uniform reaches (PEARSONS et al., 1992). Finally, at a larger scale, backwater habitats outside the main channel are refuges for fish during floods (JOWETT and RICHARDSON, 1994; ALLOUCHE et al., 1999; BELL et al., 2001), revealing the interest to maintain lateral connectivity of streams.

\section{Droughts}

Summer droughts, a natural feature of some geographic regions, are becoming increasingly frequent in other regions due to anthropogenic disturbance. They may cause mortality and decrease growth rates by reducing the volume of water available to the fish, impeding or preventing their migration, increasing biotic interactions, killing aquatic invertebrates and periphyton, and adversely affecting water quality (especially increasing water temperature and decreasing dissolved oxygen) (ELLIOTT, 2000; VILA-GISPERT et al., 2000). Generally, at low flow conditions, there is a loss of the cover that is principally located near the stream margins. As a result, the deep isolated pools become essential refugia for fish in streams subjected to frequent droughts and serve as a source of fish recolonisation (SEDELL et al., 1990; FAUSCH and BRAMBLETT, 1991; ELLIOTT, 2000; LABBE and FAUSCH, 2000). Intuitively, the role of cover in providing refuge from biotic interactions must be exacerbated during low-flow periods. Numerous individuals are confined in restricted pools with intensification of competitive interactions and predation since pools both become relatively accessible to terrestrial predators and force small taxa to remain close to piscivorous fish (MATTHEWS, 1998). But no study has explicitly evaluated the role of submerged and overhead cover during this critical period.

\section{Spawning}

Many species of Cottidae, Cyprinidae, Ictaluridae, Esocidae, and Percidae spawn on or in specific structures (woody debris, macrophytes, substratum crevices...), so instream cover is essential for their reproductive and breeding behaviour (BALON, 1975; MANN, 1996). Even species such as lampreys which generally spawn in shallow water on open, coarse bottoms have the ability to spawn beneath cover elements when environmental features (predation pressure, high flows...) become constraining (COCHRAN and GRIPENTROG, 1992). 
Spawning season is a critical stage in the life cycle of fishes, involving substantial energetic costs imposed by gamete production (mainly for females) and spawning migrations that many fishes undertake (JOBLING, 1994). Spawning and post-spawning fishes in poor condition are likely to be more susceptible to diseases and predation, so areas of cover may contribute to optimal reproduction by offering protection and places to rest (CRISP, 1996; CLOUGH et al., 1998; SEMENCHENKO, 2000). Although they generally spawn in the transitional zone between pools and riffles, the proximity of cover is sometimes a factor in the selection of spawning grounds by some salmonid species, especially for those that spend several weeks maturing near the spawning grounds (BJORNN and REISER, 1991 and references therein). Further research is required in this area as no quantitative data exist on the role of cover in governing spawning ground location and lowering spawner mortality due to predation. It is probable that the removal of cover may have disastrous consequences on the spawning success of numerous riverine fishes.

\section{Wintering}

Winter is often considered a bottleneck for populations living at high latitudes and altitudes, with low survival rates that are, however, variable among years. The abundance of cover has long been recognized as the prominent factor governing winter survival of juvenile salmonids (CUNJAK, 1996; SOLAZZI et al., 2000). SMITH and GRIFFITH (1994) indicated that the availability of cobble cover increased rainbow trout survival by $11-24 \%$ during their first winter and emphasized the thermal benefit of interstitial spaces for fish since water temperature was $0.2-1.0^{\circ} \mathrm{C}$ higher than in the overlying layers.

In response to declining temperatures and photoperiod, rising flow or icing, many stream-dwelling salmonid species exhibit a strong diurnal concealment behaviour in a wide variety of covers (MCMAHON and HARTMAN, 1989; HEGGENES et al., 1993; CONTOR and GRIFFITH, 1995; THUROW, 1997; SIMPKINS et al., 2000; VALDIMARSSON et al., 2000) but from which they emerge after sunset to maintain some feeding activity (JAKOBER et al., 2000). Daytime predation risk from diurnally endothermic predators (birds and mammals) has been suggested as the major factor governing diurnal concealment (VALDIMARSSON and METCALFE, 1998; METCALFE et al., 1999). It also reduces downstream displacement and physical injury during freshets or ice formation (BUSTARD and NARVER, 1975; TSCHAPLINSKI and HARTMAN, 1983). At a higher scale, juvenile salmonids underwent shifts towards quiet lateral habitats, small tributaries, beaver ponds or springs with groundwater acting as a thermal refugium, all of which are overwintering sites with higher survival rates than main streams (BUSTARD and NARVER, 1975; CUNJAK and POWER, 1986; JAKOBER et al., 1998).

Despite the fact that the quantity and quality of winter cover is recognized as a limiting factor for salmonid overwinter survival, further work is needed for populations distributed at lower latitudes and altitudes, that is to say experiencing considerably less severe winter conditions. More research is needed to identify winter cover features, the physiological and environmental parameters controlling wintering behaviour of riverine fishes, and the contribution of cover in reducing winter mortality.

\section{Cover use and trade-offs}

Habitat selection by individuals is a compromise between benefits (e.g. food intake) and costs (e.g. predation risk, energy expenditure). Both empirical and theoretical approaches have provided strong evidence that cover will play a prominent role in determining the outcome of these trade-offs that also depends on the physical and biological characteristics of the sites as well as on the characteristics of the individuals (GRAND and DILL, 1997). 
Patterns of use of a cover structure may vary strongly in relation with the fluctuations of environmental and biotic factors. Potentially important factors include cover occurrence, temperature, photoperiod, predation risk, conspecific density, foraging opportunities, and other factors that influence scope for activity, growth rate, and survival (FAUSCH and WHITE, 1981; TODD and RABENI, 1989; YOUNG, 1995; GIANNICO, 2000; VEHANEN et al., 2000; ARMSTRONG and GRIFFITHS, 2001). Generally, young-of-the-year avoid large accumulations of woody debris because of increased intercohort competition or predation since piscivores also use them as home sites (ANGERMEIER and KARR, 1984; LEHTINEN et al., 1997). Food availability seems to greatly control the extent of the association between fish and cover and it allows to understand the equivocal results of the literature. Field observations showed that in the summer growing season salmonids preferred to occupy open areas without cover (WILZBACH et al., 1986; BUGERT et al., 1991; HARVEY, 1998) because, by hindering the ability of these visual predators to detect prey, the drawbacks of cover may have overridden the benefits (WILZBACH, 1985; O'BRIEN and SHOWALTER, 1993). In the same way, experimental studies using behavioural titration techniques reported that in risky sites the antipredator benefits of cover can be compensated by food enrichment (GILLIAM and FRASER, 1987; GRAND and DILL, 1997; GIANNICO, 2000).

Because of its different functional roles, cover use also varies broadly among species (HEGGENES and TRAAEN, 1988; DOLLOFF and REEVES, 1990; THÉVENET, 1998), fish size or age (GRANT and NOAKES, 1987; MIKHEEV et al., 1994; REINHARDT and HEALEY, 1997), sex (ABRAHAMS and DILL, 1989), life-history strategy (HUNTINGFORD et al., 1988b; GRAND, 1999), and more generally with individual energetic status. Several studies have shown that hungry or energy-stressed (i.e. parasitized) animals had shorter hiding times or exhibited a much reduced response to predators due to their greater energetic deficits (FRASER and HUNTINGFORD, 1986; GODIN and SPROUL, 1988) so they compromised in a state-dependent fashion. Energetic constraints associated with life history strategies could also affect the extent of cover use since Atlantic salmon parrs which smolted in the spring following their birth accepted higher predation risk and used less cover than parrs which took a further year in freshwater to smolt (HUNTINGFORD et al., 1988b).

\section{MANAGEMENT CONSIDERATIONS}

Most research on ecological functions of cover structures has been on simple salmonid assemblages. Although some studies performed in lowland streams with multispecies assemblages have demonstrated strong correlation between cover and fish abundance (THÉVENET, 1998), it is likely that the functions of cover structures rely on different mechanisms in these streams. As already stated by CROOK and ROBERTSON (1999), lowland streams are characterized by slower velocities, greater depths, higher turbidity and productivity, all of which may minimize the role of cover for fish assemblages. But reaches of the medium river continuum have intermediate characteristics in which the role of cover for fish is consequent. For instance, in European streams, the barbel zone (HUET, 1959) with its diversified community rich in piscivores exemplifies the type of system where cover may have a significant role for the regulation of fish assemblages. Similarly, regulated rivers have large and shallow reaches with minimum flow (e.g. bypassed sections of the River Rhône) or unpredictable changes in flow like hydropeaking (e.g. Lower Ain River) where instream cover may have a significant role for tempering either biotic mechanisms or the effects of fluctuating hydrodynamic conditions.

Despite the recognition of the importance of cover for fish assemblages, river improvement schemes in Europe have, and still often do, advocate the removal of instream cover notably woody debris in order to maintain free flow. However, cover structures could constitute one of the levers about which it could be possible to work for restoring the 
biological integrity of degraded lowland streams. For instance, woody debris that present important carrying capacities for a large number of species and developmental stages arouse a great interest because of management perspectives (THÉVENET, 1998; PIÉGAY et al., 2000). Before enhancing the cover in a specific stream, it is necessary to really identify whether cover is a limiting factor for the populations and the functional relationships between cover structures and fish populations. Indeed, efficient restoration strategies partly depend on a clear understanding of the functions and mechanisms that link riverine fish with cover structures (GIANNICO and HEALEY, 1999; GIANNICO, 2000). Such an individual, fine-scale approach is necessary to predict the effects of a specific cover structure for fish and to understand processes at higher levels of ecological organization. This approach also allows one to better understand the spatio-temporal dynamics of cover use, an essential stage for underscoring bottlenecks during which the cover requirements of fish are crucial. Moreover, it is evident that successful cover enhancement projects also depend on larger scale habitat restoration strategies aimed at preserving both reach scale components (e.g. riparian cover) and catchment scale components (e.g. hydrologic regime, channel morphology, water quality and quantity) (PIÉGAY et al., 2000).

Moreover, whether the addition of cover structures really increases the carrying capacity of a stream or causes a redistribution of the existing capacity still remains controversial. Studies dealing with this problem are rare and concern low productivity streams (GOWAN and FAUSCH, 1996). Clearly, it would be advisable to obtain field data on this topic for lowland streams and large rivers since it is of utmost importance for all management considerations. Hence, certain cover restoration works initiated at a larger scale by management agencies will make it possible for scientists to initiate experiments with longer-term duration for overcoming natural fluctuations of populations, evaluation of the demographic processes responsible, and statistical reliability. In addition, although it is justified from a fishery purpose to commonly use cover-abundance relationships, it becomes less justified from a conservation purpose i.e. from a perspective of population maintenance or viability, since density is not necessarily a clue of the state of well-being of a population.

\section{CONCLUDING REMARKS}

Through this paper, the author has tried to highlight the numerous functions of different kinds of cover and that the mechanisms of cover use strongly vary with spatiotemporal and biological scales. She also tried to demonstrate the ambiguous nature of cover at the interface between bottom-up and top-down factors and between abiotic and biotic factors. As ectotherms, fishes have low metabolic demands at the annual scale and spend considerable time simply resting. As a consequence, one can expect the role of cover to be great in terms of population dynamics, especially for populations living at high latitudes and altitudes (i.e. in low productivity environments) where the warm growing season is short and then the inactivity period is long. Our understanding of the physical and biological linkages between fish and different kinds of cover structure throughout the river network really needs to be improved. Experimental studies are required to corroborate the results of descriptive studies and to further elucidate the potential role of cover in community dynamics. It is likely that the development of either more biologically realistic (by including prey abundance, predators or competitors) or energy-based models of habitat selection will disentangle the true functional importance of cover structures (GROSSMAN et al., 1995). For all management purposes, the key in a given stream is to directly establish the causal mechanisms for the relationship between cover and fish i.e. why and when a specific taxon uses different cover structures, and especially not to extrapolate the results from a specific stream to another. Only then can managers really establish whether cover is a subcomponent of habitat that is essential for population maintenance or not. 


\section{ACKNOWLEDGEMENTS}

We thank C. Henry, J. Labonne and P. Gaudin for fruitful discussions and comments throughout the writing, two anonymous referees for their helpful comments, and E. Pattee for providing valuable linguistic advice. This review is financially supported by the French "Conseil Supérieur de la Pêche ».

\section{REFERENCES}

ABBE T.B., MONTGOMERY D.R., 1996. Large woody debris jams, channel hydraulics and habitat formation in large rivers. Regul. Rivers: Res. Manage., 12, 201-221.

ABRAHAMS M.V., DILL L.M., 1989. A determination of the energetic equivalence of the risk of predation. Ecology, 70, 999-1007.

ALEXANDER G.R., 1979. Predators of fish in coldwater streams. In : CLEPPER H. (ed.), Predator-Prey Systems in Fisheries Management. Sport Fishing Institute, Washington, DC, 153-170.

ALLOUCHE S., THÉVENET A., GAUDIN P., 1999. Habitat use by chub (Leuciscus cephalus L. 1766) in a large river, the French Upper Rhône, as determined by radiotelemetry. Arch. Hydrobiol., 145, 219-236.

ANGERMEIER P.L., 1992. Predation by rock bass on other stream fishes: experimental effects of depth and cover. Environ. Biol. Fishes, 34, 171-180.

ANGERMEIER P.L., KARR J.R., 1984. Relationships between woody debris and fish habitat in a small warmwater stream. Trans. Am. Fish. Soc., 113, 716-726.

APARICIO E., DE SOSTOA A., 1999. Pattern of movements of adult Barbus haasi in a small Mediterranean stream. J. Fish Biol., 55, 1086-1095.

ARMSTRONG J.D., GRIFFITHS S.W.. 2001. Density-dependent refuge use among overwintering wild Atlantic salmon juveniles. J. Fish Biol., 58, 1524-1530.

BAADE U., FREDRICH F., 1998. Movement and pattern of activity of the roach in the River Spree, Germany. J. Fish Biol., 52, 1165-1174.

BACHMAN R.A., 1984. Foraging behavior of free-ranging wild and hatchery brown trout in a stream. Trans. Am. Fish. Soc., 113, 1-32.

BAIN M.B., FINN J.T., BOOKE H.E., 1985. A quantitative method for sampling riverine microhabitats by electrofishing. N. Am. J. Fish. Manage., 5, 489-493.

BAIN M.B., STEVENSON N.J. (Eds), 1999. Aquatic habitat assessment: common methods. American Fisheries Society, Bethesda, Maryland.

BALON E.K., 1975. Reproductive guilds of fishes: a proposal and definition. J. Fish. Res. Board Can., 32, 821-864.

BARAN P., DELACOSTE M., LASCAUX J.M., DAUBA F., SEGURA G., 1995. The interspecific competition between brown trout (Salmo trutta L.) and rainbow trout (Oncorhynchus mykiss Walbaum): influence on habitat models. In : GAUDIN P., SOUCHON Y., ORTH D.J., VIGNEUX E. (Eds.), Colloque " Habitat-Poissons ", Lyon/Villeurbanne, France. Bull. Fr. Pêche Piscic., 337/338/339, 283-290.

BECHARA J.A., MOREAU G., HARE L., 1993. The impact of brook trout (Salvelinus fontinalis) on an experimental stream benthic community: the role of spatial and size refugia. J. Anim. Ecol., 62, 451-464.

BELL E., DUFFY W.G., ROELOFS T.D., 2001. Fidelity and survival of juvenile coho salmon in response to a flood. Trans. Am. Fish. Soc., 130, 450-458.

BENKE A.C., HENRY R.L., GILLESPIE D.M., HUNTER R.J., 1985. Importance of snag habitat for animal production in southeastern streams. Fisheries, 10, 8-13.

BILBY R.E., WARD J.W., 1989. Changes in characteristics and function of woody debris with increasing size of streams in western Washington. Trans. Am. Fish. Soc., 118, 368-378.

BINNS N.A., EISERMANN F.M., 1979. Quantification of fluvial trout habitat in Wyoming. Trans. Am. Fish. Soc., 108, 215-228. 
BJORNN T.C., 1971. Trout and salmon movements in two Idaho streams as related to temperature, food, stream flow, cover and population density. Trans. Am. Fish. Soc., $100,423-438$.

BJORNN T.C., KIRKING S.C., MEEHAN W.R., 1991. Relation of cover alterations to the summer standing crop of young salmonids in small southeast Alaska streams. Trans. Am. Fish. Soc., 120, 562-570.

BJORNN T.C., REISER D.W., 1991. Habitat requirements of salmonids in streams. In : MEEHAN W.R. (ed.), Influences of forest and rangeland management on salmonid fishes and their habitats. Am. Fish. Soc. Spec. Publ., 19, 83-138.

BOHNSACK J.A., 1989. Are high densities of fishes at artificial reefs the result of habitat limitation or behavioral preference? Bull. Mar. Sci., 44, 631-645.

BOUSSU M.F., 1954. Relationship between trout populations and cover on a small stream. J. Wildl. Manage., 18, 229-239.

BOVEE K.D., 1982. A guide to stream habitat analysis using the Instream Flow Incremental Methodology. Instream Flow Information Paper $n^{\circ} 12$, FWS/OBS 82/86., Western Energy and Land Use Team, U.S. Fish and Wildlife Service, Fort Collins, Colorado.

BRIDCUT E.E., 2000. A study of terrestrial and aerial macroinvertebrates on river banks and their contribution to drifting fauna and salmonid diets in a Scottish catchment. Hydrobiologia, 427, 83-100.

BRUSVEN M.A., MEEHAN W.R., WARD J.F., 1986. Summer use of simulated undercut banks by juvenile chinook salmon in an artificial idaho channel. N. Am. J. Fish. Manage., 6, 32-37.

BUGERT R.M., BJORNN T.C., 1991. Habitat use by steelhead and coho salmon and their responses to predators and cover in laboratory streams. Trans. Am. Fish. Soc., 120, 486-493.

BUGERT R.M., BJORNN T.C., MEEHAN W.R., 1991. Summer habitat use by young salmonids and their responses to cover and predators in a small southeast alaska stream. Trans. Am. Fish. Soc., 120, 474-485.

BUSTARD D.R., NARVER D.W., 1975. Aspects of the winter ecology of juvenile coho salmon (Oncorhynchus kisutch) and steelhead trout (Salmo gairdneri). J. Fish. Res. Board Can., 32, 667-680.

CARON J., BEAUGRAND J.P., 1988. Social and spatial structure in brook chars (Salvelinus fontinalis) under competition for food and shelter/shade. Behav. Proces., 16, 173-191.

CLOUGH S., GARNER P., DEANS D., LADLE M., 1998. Postspawning movements and habitat selection of dace in the River Frome, Dorset, southern England. J. Fish Biol., 53, 1060-1070.

COCHRAN P.A., GRIPENTROG A.P., 1992. Aggregation and spawning by lampreys (genus Ichthyomyzon) beneath cover. Environ. Biol. Fishes, 33, 381-387.

COGERINO L., CELLOT B., BOURNAUD M., 1995. Microhabitat diversity and associated macroinvertebrates in aquatic banks of a large European river. Hydrobiologia, 304, 103-115.

COLLARES-PEREIRA M.J., MAGALHAES M.F., GERALDES A.M., COELHO M.M., 1995. Riparian ecotones and spatial variation of fish assemblages in Portuguese lowland streams. Hydrobiologia, 303, 93-101.

CONTOR C.R., GRIFFITH J.S., 1995. Nocturnal emergence of juvenile rainbow trout from winter concealment relative to light intensity. Hydrobiologia, 299, 179-183.

COPP G.H., BENNETTS T.A., 1996. Short-term effects of removing riparian and instream cover on barbel (Barbus barbus) and other fish populations in a stretch of english chalk stream. Folia Zool., 45, 283-288.

COUTANT C.C. 1996. Comment: effects of instream brush on juvenile coho salmon. Trans. Am. Fish. Soc., 125, 150-151.

COWX I.G., WHEATLEY G.A., MOSLEY A.S., 1986. Long-term effects of land drainage works on fish stocks in the upper reaches of a lowland river. J. Environ. Manage., 22, 147-156. 
CRISP D.T., 1996. Environmental requirements of common riverine European salmonid fish species in fresh water with particular reference to physical and chemical aspects. Hydrobiologia, 323, 201-221.

CROOK D.A., ROBERTSON A.I., 1999. Relationships between riverine fish and woody debris: implications for lowland rivers. Mar. Freshwater Res., 50, 941-953.

CROWDER L.B., COOPER W.E., 1978. Structural complexity and fish-prey interactions in ponds: a point of view. In : JOHNSON D.L., STEIN R.A. (Eds.), Response of fish to habitat structure in standing water, Columbus, Ohio, USA. Am. Fish. Soc. Spec. Publ., 6, 2-10.

CROWDER L.B., COOPER W.E., 1982. Habitat structural complexity and the interaction between bluegills and their prey. Ecology, 63, 1802-1813.

CULP J.M., SCRIMGEOUR G.J., TOWNSEND G.D., 1996. Simulated fine woody debris accumulations in a stream increase rainbow trout fry abundance. Trans. Am. Fish. Soc., $125,472-479$.

CUNJAK R.A., 1996. Winter habitat of selected stream fishes and potential impacts from land-use activity. Can. J. Fish. Aquat. Sci., 53, 267-282.

CUNJAK R.A., GREEN J.M., 1983. Habitat utilization by brook char (Salvelinus fontinalis) and rainbow trout (Salmo gairdneri) in Newfoundland streams. Can. J. Zool., 61, 1214-1219.

CUNJAK R.A., POWER G., 1986. Winter habitat utilization by stream resident brook trout (Salvelinus fontinalis) and brown trout (Salmo trutta). Can. J. Fish. Aquat. Sci., 43, 1970-1981.

CUNJAK R.A., POWER G., 1987. Cover use by stream-resident trout in winter: a field experiment. N. Am. J. Fish. Manage., 7, 539-544.

DEVORE P.W., WHITE R.J., 1978. Daytime responses of brown trout (Salmo trutta) to cover stimuli in stream channels. Trans. Am. Fish. Soc., 107, 763-771.

DIEHL S., 1988. Foraging efficiency of three freshwater fishes: effects of structural complexity and light. Oikos, 53, 207-214.

DILL L.M., 1990. Distance-to-cover and the escape decisions of an African cichlid fish, Melanochromis chipokae. Environ. Biol. Fishes, 27, 147-152.

DOLLOFF C.A., 1986. Effects of stream cleaning on juvenile coho salmon and dolly varden in Southeast Alaska. Trans. Am. Fish. Soc., 115, 743-755.

DOLLOFF C.A., REEVES G.H., 1990. Microhabitat partitioning among stream-dwelling juvenile coho salmon, Oncorhynchus kisutch, and Dolly Varden, Salvelinus malma. Can. J. Fish. Aquat. Sci., 47, 2297-2306.

DOUGLAS M., LAKE P.S., 1994. Species richness of stream stones: an investigation of the mechanisms generating the species-area relationship. Oikos, 69, 387-396.

DOWNES B.J., LAKE P.S., SCHREIBER E.S.G., GLAISTER A., 1998. Habitat structure and regulation of local species diversity in a stony, upland stream. Ecol. Monogr., 68, 237-257.

DRAULANS D., 1988. Effects of fish-eating birds on freshwater fish stocks: an evaluation. Biol. Conserv., 44, 251-263.

DUDLEY T.L., ANDERSON N.H., 1982. A survey of invertebrates associated with wood debris in aquatic habitats. Melanderia, 39, 1-21.

EKLÖV P., 1997. Effects of habitat complexity and prey abundance on the spatial and temporal distributions of perch (Perca fluviatilis) and pike (Esox lucius). Can. J. Fish. Aquat. Sci., 54, 1520-1531.

EKLÖV P., PERSSON L., 1995. Species-specific antipredator capacities and prey refuges: interactions between piscivorous perch (Perca fluviatilis) and juvenile perch and roach (Rutilus rutilus). Behav. Ecol. Sociobiol., 37, 169-178.

ELLIOT S.T., 1986. Reduction of a Dolly Varden population and macrobenthos after removal of logging debris. Trans. Am. Fish. Soc., 115, 392-400.

ELLIOTT J.M., 2000. Pools as refugia for brown trout during two summer droughts: trout responses to thermal and oxygen stress. J. Fish Biol., 56, 938-948.

ELTON C., 1939. On the nature of cover. J. Wildl. Manage., 3, 332-338. 
EVERETT R.A., RUIZ G.M., 1993. Coarse woody debris as a refuge from predation in aquatic communities. Oecologia, 93, 475-486.

FACEY D.E., GROSSMAN G.D., 1990. The metabolic cost of maintaining position for four North American stream fishes: effects of season and velocity. Physiol. Zool., 63, 757-776.

FAUSCH K.D., 1984. Profitable stream positions for salmonids: relating specific growth rate to net energy gain. Can. J. Zool., 62, 441-451.

FAUSCH K.D., 1993. Experimental analysis of microhabitat selection by juvenile steelhead (Oncorhynchus mykiss) and coho salmon (O. kisutch) in a British Columbia stream. Can. J. Fish. Aquat. Sci., 50, 1198-1207.

FAUSCH K.D., WHITE R.J., 1981. Competition between brook trout (Salvelinus fontinalis) and brown trout (Salmo trutta) for positions in a Michigan stream. Can. J. Fish. Aquat. Sci., 38, 1220-1227.

FAUSCH K.D., HAWKES C.L., PARSONS M.G., 1988. Models that predict standing crop of stream fish from habitat variables: 1950-85. Gen. Tech. Rep. PNW-GTR-213, U.S. Department of Agriculture, Forest Service, Pacific Northwest Research Station, Portland, OR. 52 p.

FAUSCH K.D., BRAMBLETT R.G., 1991. Disturbance and fish communities in intermittent tributaries of a western Great Plains river. Copeia, 3, 659-674.

FAUSCH K.D., NORTHCOTE T.G., 1992. Large woody debris and salmonid habitat in a small coastal British Columbia stream. Can. J. Fish. Aquat. Sci., 49, 682-693.

FAUSCH K.D., GOWAN C., RICHMOND A.D., RILEY S.C., 1995. The role of dispersal in trout population response to habitat formed by large woody debris in Colorado mountain streams. In : GAUDIN P., SOUCHON Y., ORTH D.J., VIGNEUX E. (Eds.), Colloque " Habitat-Poissons ", Lyon/Villeurbanne, France. Bull. Fr. Pêche Piscic., 337/338/339, 179-190.

FLEBBE P.A., DOLLOFF C.A., 1995. Trout use of woody debris and habitat in Appalachian wilderness streams of North Carolina. N. Am. J. Fish. Manage., 15, 579-590.

FLECKER A.S., 1992. Fish trophic guilds and the structure of a tropical stream: weak direct vs strong indirect effects. Ecology, 73, 927-940.

FRAGNOUD E., 1987. Préférences d'habitat de la truite fario (Salmo trutta fario L.,1758) en rivière (quelques cours d'eau du sud-est de la France). Ph. D Thesis, Lyon 1 University, France.

FRASER D.F., 1983. An experimental investigation of refuging behaviour in a minnow. Can. J. Zool., 61, 666-672.

FRASER D.F., CERRI R.D., 1982. Experimental evaluation of predator-prey relationships in a patchy environment: consequences for habitat use patterns in minnows. Ecology, 63, 307-313.

FRASER D.F., HUNTINGFORD F.A., 1986. Feeding and avoiding predation hazard: the behavioral response of the prey. Ethology, 73, 56-68.

FRASER D.F., GILLIAM J.F., 1992. Nonlethal impacts of predator invasion: facultative suppression of growth and reproduction. Ecology, 73, 959-970.

GELWICK F.P., 1995. Effects of grazers and their shared predator on algal heterogeneity: consequences for streamfish interactions. Ph.D. dissertation. University of Oklahoma, Norman.

GIANNICO G.R., 2000. Habitat selection by juvenile coho salmon in response to food and woody debris manipulations in suburban and rural stream sections. Can. J. Fish. Aquat. Sci., 57, 1804-1813.

GIANNICO G.R., HEALEY M.C., 1999. Ideal free distribution theory as a tool to examine juvenile coho salmon (Oncorhynchus kisutch) habitat choice under different conditions of food abundance and cover. Can. J. Fish. Aquat. Sci., 56, 2362-2373.

GIBSON R.J., 1978. The behavior of juvenile Atlantic salmon (Salmo salar) and brook trout (Salvelinus fontinalis) with regard to temperature and to water velocity. Trans. Am. Fish. Soc., 107, 703-712.

GILLIAM J.F., FRASER D.F., 1987. Habitat selection under predation hazard: test of a model with foraging minnows. Ecology, 68, 1856-1862. 
GIPPEL C.J., O’NEILL I.C., FINLAYSON B.L., SCHNATZ I., 1996. Hydraulic guidelines for the re-introduction and management of large woody debris in lowland rivers. Regul. Rivers: Res. Manage., 12, 223-236.

GODIN J.-G.J., SPROUL C.D., 1988. Risk taking in parasitized sticklebacks under threat of predation: effects of energetic need and food availability. Can. J. Zool., 66, 2360-2367.

GORE J.A., SHIELDS F.D., 1995. Can large rivers be restored? BioScience, 45, 142-152.

GORMAN O.T., KARR J.R., 1978. Habitat structure and stream fish communities. Ecology, 59, 507-515.

GOTCEITAS V., COLGAN P., 1989. Predator foraging success and habitat complexity: quantitative test of the threshold hypothesis. Oecologia, 80, 158-166.

GOWAN C., FAUSCH K.D., 1996. Long-term demographic responses of trout populations to habitat manipulation in six Colorado streams. Ecol. Appl., 6, 931-946.

GRAND T.C., 1999. Risk-taking behaviour and the timing of life history events: consequences of body size and season. Oikos, 85, 467-480.

GRAND T.C., DILL L.M., 1997. The energetic equivalence of cover to juvenile coho salmon (Oncorhynchus kisutch): ideal free distribution theory applied. Behav. Ecol., 8, 437-447.

GRANDMOTTET J.P., 1983. Principales exigences des téléostéens dulcicoles vis-à-vis de I'habitat aquatique. Ann. Sci. Univ. Besançon, 4, 3-32.

GRANT J.W.A., NOAKES D.L.G., 1987. Escape behaviour and use of cover by young-ofthe-year brook trout, Salvelinus fontinalis. Can. J. Fish. Aquat. Sci., 44, 1390-1396.

GREGORY R.S., 1993. Effect of turbidity on the predator avoidance behaviour of juvenile chinook salmon (Oncorhynchus tshawytscha). Can. J. Fish. Aquat. Sci., 50, 241-246.

GREGORY J.S., GRIFFITH J.S., 1996. Aggressive behaviour of underyearling rainbow trout in simulated winter concealment habitat. J. Fish Biol., 49, 237-245.

GRIFFITH J.S., SMITH R.W., 1993. Use of winter concealment cover by juvenile cutthroat and brown trout in the south fork of the Snake river, Idaho. N. Am. J. Fish. Manage., 13, 823-830.

GROSSMAN G.D., HILL J., PETTY J.T., 1995. Observations on habitat structure, population regulation, and habitat use with respect to evolutionarily significant units: a landscape perspective for lotic systems. In : NIELSEN J.L. (ed.), Evolution and the aquatic ecosystem: defining unique units in population conservation, Bethesda, Maryland. Am. Fish. Soc. Symp., 17, 381-391.

GROSSMAN G.D., JONES G.P., SEAMAN W.J., 1997. Do artificial reefs increase regional fish production? A review of existing data. Fisheries, 22 (4), 17-23.

GUÉGAN J.F., LEK S., OBERDORFF T., 1998. Energy availability and habitat heterogeneity predict global riverine fish diversity. Nature, 391, 382-384.

GUENSCH G.R., HARDY T.B., ADDLEY R.C., 2001. Examining feeding strategies and position choice of drift-feeding salmonids using an individual-based, mechanistic foraging model. Can. J. Fish. Aquat. Sci., 58, 446-457.

GURNELL A.M., GREGORY K.J., PETTS G.E., 1995. The role of coarse woody debris in forest aquatic habitats: implications for management. Aquat. Conserv.: Mar. Freshwater Ecosystems, 5, 143-166.

HAINES T.A., BUTLER R.L., 1969. Responses of yearling smallmouth bass (Micropterus dolomieui) to artificial shelter in a stream aquarium. J. Fish. Res. Board Can., 26, 21-31.

HARMON M.E., FRANKLIN J.F., SWANSON F.J., SOLLINS P., GREGORY S.V., LATTIN J.D., ANDERSON N.H., CLINE S.P., AUMEN N.G., SEDELL J.R., LIENKAEMPER G.W., CROMACK K.J., CUMMINS K.W., 1986. Ecology of coarse woody debris in temperate ecosystems. In : MACFADAYEN A., FORD E.D. (Eds.), Advances in Ecological Research. Academic Press, London, 133-302.

HARVEY B.C., 1998. Influence of large woody debris on retention, immigration, and growth of coastal cutthroat trout (Oncorhynchus clarki clarki) in stream pools. Can. J. Fish. Aquat. Sci., 55, 1902-1908. 
HARVEY B.C., STEWART A.J., 1991. Fish size and habitat depth relationships in headwater streams. Oecologia, 87, 336-342.

HARVEY B.C., NAKAMOTO R.J., WHITE J.L., 1999. Influence of large woody debris and a bankfull flood on movement of adult resident coastal cutthroat trout (Oncorhynchus clarki) during fall and winter. Can. J. Fish. Aquat. Sci., 56, 2161-2166.

HAURY J., BAGLINIĖRE J.L., 1996. Les macrophytes, facteur structurant de l'habitat piscicole en rivière à Salmonidae. Etude de la microrépartition sur un secteur végétalisé du Scorff (Bretagne-Sud). Cybium, 20, 111-127.

HAX C.L., GOLLADAY S.W., 1993. Macroinvertebrate colonization and biofilm development on leaves and wood in a boreal river. Freshwater Biol., 29, 79-97.

HECK JR. K.L., CROWDER L.B., 1991. Habitat structure and predator-prey interactions in vegetated aquatic systems. In : BELL S.S., MCCOY E.D., MUSHINSKY H.R. (Eds.), Habitat structure: the physical arrangement of objects in space. Chapman and Hall, London, 281-295.

HEGGENES J., 1988a. Effects of short-term flow fluctuations on displacement of, and habitat use by, brown trout in a small stream. Trans. Am. Fish. Soc., 117, 336-344.

HEGGENES J., 1988b. Substrate preferences of brown trout fry (Salmo trutta) in artificial stream channels. Can. J. Fish. Aquat. Sci., 45, 1801-1806.

HEGGENES J., TRAAEN T., 1988. Daylight responses to overhead cover in stream channels for fry four salmonid species. Holartic Ecol., 11, 194-201.

HEGGENES J., BRABRAND A., SALTVEIT S.J., 1990. Comparison of three methods for studies of stream habitat use by young brown trout and Atlantic salmon. Trans. Am. Fish. Soc., 119, 101-111.

HEGGENES J., BRABRAND A., SALTVEIT S.J., 1991. Microhabitat use by brown trout, Salmo trutta L. and Atlantic salmon, S. salar L., in a stream: a comparative study of underwater and river bank observations. J. Fish Biol., 38, 259-266.

HEGGENES J., KROG O.M.W., LINDAS O.R., DOKK J.G., BREMNES T., 1993. Homeostatic behavioural responses in a changing environment: brown trout (Salmo trutta) become nocturnal during winter. J. Anim. Ecol., 62, 295-308.

HELFMAN G.S., 1979. Fish attraction to floating objects in lakes. In : JOHNSON D.L., STEIN R.A. (Eds.), Response of fish to habitat structure in standing water, Columbus, Ohio, USA. Am. Fish. Soc. Spec. Publ., 6, 49-57.

HELFMAN G.S., 1981. The advantage to fishes of hovering in shade. Copeia, 2, 392-400.

HERMANSEN H., KROG C., 1984. Influence of physical factors on density of stocked brown trout (Salmo trutta fario L.) in a Danish Lowland stream. Fish. Manage., 15, 107-115.

HILDREW A.G., 1992. Food webs and species interactions. In : CALOW P., PETTS G.E. (Eds.), The Rivers Handbook-Hydrological and Ecological Principles. Blackwell Scientific Publications, Oxford, 309-330.

HILL J., GROSSMAN G.D., 1993. An energetic model of microhabitat use for rainbow trout and rosyside dace. Ecology, 74, 685-698.

HOLIERHOEK A.M., POWER G., 1995. Responses of wild juvenile Arctic charr to cover, light and predator threat. Nord. J. Freshwater Res., 71, 296-308.

HOUSE R.A., BOEHNE P.L., 1985. Evaluation of instream enhancement structures for salmonid spawning and rearing in a coastal Oregon stream. N. Am. J. Fish. Manage., 5, 283-295.

HOUSE R.A., BOEHNE P.L., 1986. Effects of instream structures on salmonid habitat and populations in Tobe Creek, Oregon. N. Am. J. Fish. Manage., 6, 38-46.

HUET M., 1959. Profiles and biology of Western European streams as related to fish management. Trans. Am. Fish. Soc., 88, 155-163.

HUGHES N.F., 1992. Ranking of feeding positions by drift-feeding Arctic grayling (Thymallus arcticus) in dominance hierarchies. Can. J. Fish. Aquat. Sci., 49, 1994-1998. 
HUGHES N.F., DILL L.M., 1990. Position choice by drift-feeding salmonids: model and test for Arctic grayling (Thymallus arcticus) in subarctic mountain streams, interior Alaska. Can. J. Fish. Aquat. Sci., 47, 2039-2048.

HUNTINGFORD F.A., METCALFE N.B., THORPE J.E., 1988a. Choice of feeding station in Atlantic salmon, Salmo salar, parr: effects of predation risk, season and life history strategy. J. Fish Biol., 33, 917-924.

HUNTINGFORD F.A., METCALFE N.B., THORPE J.E., 1988b. Feeding motivation and response to predation risk in Atlantic salmon parr adopting different life history strategies. J. Fish Biol., 32, 777-782.

ILLIES J., BOTOSANEANU L., 1963. Problèmes et méthodes de la classification et de la zonation écologique des eaux courantes, considérées surtout du point de vue faunistique. Mitt. Int. Ver. Theor. Angew. Limnol., 12, 1-57.

INOUE M., NAKANO S., 1998. Effects of woody debris on the habitat of juvenile masu salmon (Oncorhynchus masou) in northern Japanese streams. Freshwater Biol., 40, 1-16.

JAKOBER M.J., MCMAHON T.E., THUROW R.F., CLANCY C.G., 1998. Role of stream ice on fall and winter movements and habitat use by bull trout and cutthroat trout in Montana headwater streams. Trans. Am. Fish. Soc., 127, 223-235.

JAKOBER M.J., MCMAHON T.E., THUROW R.F., 2000. Diel habitat partitioning by bull charr and cutthroat trout during fall and winter in Rocky Mountain streams. Environ. Biol. Fishes, 59, 79-89.

JOBLING M., 1994. Fish Bioenergetics. Chapman \& Hall, London. 309 p.

JOHNSON S.L., 1993. Cover choice by bluegills: orientation of underwater structure and light intensity. Trans. Am. Fish. Soc., 122, 148-154.

JOHNSON S.W., HEIFETZ J., KOSKI K.V., 1986. Effects of logging on the abundance and seasonal distribution of juvenile steelhead in some southeastern Alaska streams. N. Am. J. Fish. Manage., 6, 532-537.

JOWETT I.G., RICHARDSON J., 1989. Effects of a severe flood on instream habitat and trout populations in seven New Zealand rivers. N. Zeal. J. Mar. Freshwater Res., 23, 11-17.

JOWETT I.G., RICHARDSON J., 1994. Comparison of habitat use by fish in normal and flooded river conditions. N. Zeal. J. Mar. Freshwater Res., 28, 409-416.

KALLEBERG H., 1958. Observations in a stream tank of territoriality and competition in juvenile salmon and trout (Salmo salar L. and salmo trutta L.). Rep. Inst. Fresh. Res. Drottningholm, 39, 55-98.

KATS L.B., DILL L.M., 1998. The scent of death: Chemosensory assessment of predation risk by prey animals. Ecoscience, 5, 361-394.

KAWAGUCHI Y., NAKANO S., 2001. Contribution of terrestrial invertebrates to the annual resource budget for salmonids in forest and grassland reaches of a headwater stream. Freshwater Biol., 46, 303-316.

KEITH R.M., BJORNN T.C., MEEHAN W.R., HETRICK N.J., BRUSVEN M.A., 1998. Response of juvenile salmonids to riparian and instream cover modifications in small streams flowing through second-growth forests of southeast Alaska. Trans. Am. Fish. Soc., 127, 889-907.

KIEFFER J.D., COLGAN P.W., 1992. The role of learning in fish behaviour. Rev. Fish Biol. Fish., 2, 125-143.

KINSOLVING A.D., BAIN M.B., 1990. A new approach for measuring cover in fish habitat studies. J. Freshwater Ecol., 5, 373-378.

LABBE T.R., FAUSCH K.D., 2000. Dynamics of intermittent stream habitat regulate persistence of a threatened fish at multiple scales. Ecol. Appl., 10, 1774-1791.

LAMMENS E.H.R.R., HOOGENBOEZEM W., 1991. Diets and feeding behaviour. In : WINFIELD I.J., NELSON J.S. (Eds.), Cyprinid fishes: systematics, biology and exploitation, London, 353-376.

LANGFORD T.E., HAWKINS S.J., 1997. The distribution and abundance of three fish species in relation to timber debris and mesohabitats in a lowland forest stream during autumn and winter. Limnetica, 13, 93-102. 
LEHTINEN R.M., MUNDAHL N.D., MADEJCZYK J.C., 1997. Autumn use of woody snags by fishes in backwater and channel border habitats of a large river. Environ. Biol. Fishes, 49, 7-19.

LEWIS S.L., 1969. Physical factors influencing fish populations in pools of a trout stream. Trans. Am. Fish. Soc., 98, 14-19.

LIM P., SEGURA G., BELAUD A., SABATON C., 1993. Study of the habitat of brown trout (Salmo trutta fario). Role of artificial and natural covers on trout populations. Bull. Fr. Pêche Piscic., 331, 373-396.

LIMA S.L., 1998. Stress and decision making under the risk of predation: recent developments from behavioral, reproductive and ecological perspectives. Adv. Study Behav., 27, 215-290.

LONZARICH D.G., QUINN T.P., 1995. Experimental evidence for the effect of depth and structure on the distribution, growth and survival of stream fishes. Can. J. Zool., 73, 2223-2230.

LUCAS M.C., BARAS E., 2000. Methods for studying spatial behaviour of freshwater fishes in the natural environment. Fish and Fisheries, 1, 283-316.

LYNCH JR W.E., JOHNSON D.L., 1989. Influences of interstice size, shade, and predators on the use of artificial structures by bluegills. N. Am. J. Fish. Manage., 9, 219-225.

MAITLAND P.S., 1995. The conservation of freshwater fish: past and present experience. Biol. Conserv., 72, 259-270.

MANN R.H.K., 1996. Environmental requirements of European non-salmonid fish in rivers. Hydrobiologia, 323, 223-235.

MASON C.F., MACDONALD S.M., 1982. The input of terrestrial invertebrates from tree canopies to a stream. Freshwater Biol., 12, 305-311.

MATTHEWS W.J., 1998. Patterns in Freshwater Fish Ecology, Chapman and Hall (Eds.). Kluwer Academic Publishers. 756 p.

MCCARTT A.L., LYNCH JR W.E., JOHNSON D.L., 1997. How light, a predator, and experience influence bluegill use of shade and schooling. Environ. Biol. Fishes, 49, 79-87.

MCCRIMMON H., KWAIN W.H., 1966. Use of overhead cover by rainbow trout exposed to a series of light intensities. J. Fish. Res. Board Can., 23, 983-990.

MCLEAN E.B., GODIN J.-G.J., 1989. Distance to cover and fleeing from predators in fish with different amounts of defensive armour. Oikos, 55, 281-290.

MCMAHON T.E., HARTMAN G.F., 1989. Influence of cover complexity and current velocity on winter habitat use by juvenile coho salmon (Oncorhynchus kisutch). Can. J. Fish. Aquat. Sci., 46, 1551-1557.

MCNAIR J.N., 1986. The effects of refuges on predator-prey interactions: a reconsideration. Theor. Popul. Biol., 29, 38-63.

MEEHAN W.R., BRUSVEN M.A., WARD J.F., 1987. Effects of shading on distribution and abundance of juvenile chinook salmon. Great Basin Nat., 47, 22-31.

MESICK C.F., 1988. Effects of food and cover on numbers of apache and brown trout establishing residency in artificial stream channels. Trans. Am. Fish. Soc., 117, 421-431.

METCALFE N.B., FRASER N.H.C., BURNS M.D., 1999. Food availability and the nocturnal vs diurnal foraging trade-off in juvenile salmon. J. Anim. Ecol., 68, 371-381.

MIKHEEV V.N., METCALFE N.B., HUNTINGFORD F.A., THORPE J.E., 1994. Size-related differences in behaviour and spatial distribution of juvenile Atlantic salmon in a novel environment. J. Fish Biol., 45, 379-386.

MITTELBACH G., 1986. Predator-mediated habitat use: some consequences for species interactions. Environ. Biol. Fishes, 16, 159-169.

MONZYK F.R., KELSO W.E., RUTHERFORD D.A., 1997. Characteristics of woody cover used by brown madtoms and pirate perch in coastal plain streams. Trans. Am. Fish. Soc., 126, 665-675.

MORING J.R., NICHOLSON P.H., 1994. Evaluation of three types of artificial habitats for fishes in a freshwater pond in Maine, USA. Bull. Mar. Sci., 55, 1149-1159. 
MORTENSEN E., 1977. Density-dependent mortality of trout fry and its relationship to the management of small streams. J. Fish Biol., 11, 613-617.

MURPHY M.L., HEIFETZ J., JOHNSON S.W., KOSKI K.V., THEDINGA J.F., 1986. Effects of clear-cut logging with and without buffer strips on juvenile salmonids in Alaskan streams. Can. J. Fish. Aquat. Sci., 43, 1521-1533.

NELSON N.G., BONSDORFF E., 1990. Fish predation and habitat complexity: are complexity threshols real? J. Exp. Mar. Biol. Ecol., 141, 183.

NIELSEN G., 1986. Dispersion of brown trout (Salmo trutta L.) in relation to stream cover and water depth. Pol. Arch. Hydrobiol., 33, 475-488.

NIELSEN J.L., 1992. Microhabitat-specific foraging behavior, diet, and growth of juvenile coho salmon. Trans. Am. Fish. Soc., 121, 617-634.

O'BRIEN W.J., SHOWALTER J.J., 1993. Effects of current velocity and suspended debris on the drift feeding of Arctic grayling. Trans. Am. Fish. Soc., 122, 609-615.

O'CONNOR N.A., 1991. The effects of habitat complexity on the macroinvertebrates colonising wood substrates in a lowland stream. Oecologia, 85, 504-512.

PEARSONS T.N., LI H.W., LAMBERTI G.A., 1992. Influence of habitat complexity on resistance to flooding and resilience of stream fish assemblages. Trans. Am. Fish. Soc., 121, 427-436.

PENCZAK T., 1995. Effects of removal and regeneration of bankside vegetation on fish population dynamics in the Warta River, Poland. Hydrobiologia, 303, 207-210.

PERSSON L., 1993. Predator-mediated competition in prey refuges: the importance of habitat dependent prey resources. Oikos, 68, 12-22.

PHILLIPS E.C., KILAMBI R.V., 1994. Use of coarse woody debris by Diptera in Ozark streams, Arkansas. J. North Am. Benthol. Soc., 13, 151-159.

PIÉGAY H., THÉVENET A., KONDOLF G.M., LANDON N., 2000. Physical and human factors influencing potential fish habitat distribution along a Mountain River, France. Geogr. Ann., 82 A, 121-136.

POWER M.E., 1983. Grazing responses of tropical freshwater fishes to different scales of variation in their food. Environ. Biol. Fishes, 9, 103-115.

POWER M.E., 1987. Predator avoidance by grazing fishes in temperate and tropical streams: Importance of stream depth and prey size. In : KERFOOT W.C., SIH A. (Eds.), Predation: Direct and Indirect Impacts on Aquatic Communities. University Press of New England, Hanover, 333-351.

POWER M.E., 1992. Habitat heterogeneity and the functional significance of fish in river food webs. Ecology, 73, 1675-1688.

POWER M.E., MATTHEWS W.J., STEWART A.J., 1985. Grazing minnows, piscivorous bass, and stream algae: dynamics of a strong interaction. Ecology, 66, 1448-1456.

QUINN T.P., PETERSON N.P., 1996. The influence of habitat complexity and fish size on over-winter survival and growth of individually marked juvenile coho salmon (Oncorhynchus kisutch) in Big Beef Creek, Washington. Can. J. Fish. Aquat. Sci., 53, 1555-1564.

RAHEL F.J., STEIN R.A., 1988. Complex predator-prey interactions and predator intimidation among crayfish, piscivorous fish, and small benthic fish. Oecologia, 75, 94-98.

REINHARDT U.G., HEALEY M.C., 1997. Size-dependent foraging behaviour and use of cover in juvenile coho salmon under predation risk. Can. J. Zool., 75, 1642-1651.

RICHMOND A.D., FAUSCH K.D., 1995. Characteristics and function of large woody debris in subalpine Rocky Mountain streams in northern Colorado. Can. J. Fish. Aquat. Sci., 52, 1789-1802.

RILEY S.C., FAUSCH K.D., GOWAN C., 1992. Movement of brook trout (Salvelinus fontinalis) in four small subalpine streams in northern Colorado. Ecol. Freshwater Fish, 1, 112-122.

RILEY S.C., FAUSCH K.D., 1995. Trout population response to habitat enhancement in six northern Colorado streams. Can. J. Fish. Aquat. Sci., 52, 34-53.

RIMMER D.M., PAIM U., SAUNDERS R.L., 1983. Autumnal habitat shift of juvenile Atlantic salmon (Salmo salar) in a small river. Can. J. Fish. Aquat. Sci., 40, 671-680. 
ROBISON E.G., BESCHTA R.L., 1990. Characteristics of coarse woody debris for several coastal streams of Southeast Alaska, USA. Can. J. Fish. Aquat. Sci., 47, 1684-1693.

RONI P., QUINN T.P., 2001a. Effects of wood placement on movements of trout and juvenile coho salmon in natural and artificial stream channels. Trans. Am. Fish. Soc., 130, 675-685.

RONI P., QUINN T.P., 2001b. Density and size of juvenile salmonids in response to placement of large woody debris in western Oregon and Washington streams. Can. J. Fish. Aquat. Sci., 58, 282-292.

ROZAS L.P., ODUM W.E., 1988. Occupation of submerged aquatic vegetation by fishes: testing the roles of food and refuge. Oecologia, 77, 101-106.

SAUNDERS J.W., SMITH M.W., 1962. Physical alteration of stream habitat to improve brook trout production. Trans. Am. Fish. Soc., 91, 185-188.

SAVINO J.F., STEIN R.A., 1982. Predator-prey interaction between largemouth bass and bluegills as influenced by simulated, submersed vegetation. Trans. Am. Fish. Soc., 111, 255-266.

SAVINO J.F., STEIN R.A., 1989. Behavioural interactions between fish predators and their prey: effects of plant density. Anim. Behav., 37, 311-321.

SAVINO J.F., MARSCHALL E.A., STEIN R.A., 1992. Bluegill growth as modified by plant density: an exploration of underlying mechanisms. Oecologia, 89, 153-160.

SCHIEMER F., ZALEWSKI M., 1992. The importance of riparian ecotones for diversity and productivity of riverine fish communities. Netherlands J. Zool., 42, 323-335.

SCHIEMER F., ZALEWSKI M., THORPE J.E. (Eds.), 1995. The importance of aquaticterrestrial ecotones for freshwater fish, Hydrobiologia, 303.

SCHLOSSER I.J., 1982. Fish community structure and function along two habitat gradients in a headwater stream. Ecol. Monogr., 52, 395-414.

SCHLOSSER I.J., 1985. Flow regime, juvenile abundance, and the assemblage structure of stream fishes. Ecology, 66, 1484-1490.

SCHLOSSER I.J., 1987. The role of predation in age- and size-related habitat use by stream fishes. Ecology, 68, 651-659.

SEDELL J.R., REEVES G.H., RICHARD HAUER F., STANFORD J.A., HAWKINS C.P., 1990. Role of refugia in recovery from disturbances: modern fragmented and disconnected river systems. Environ. Manage., 14, 711-724.

SEMENCHENKO A., 2000. The role of riverine woody debris accumulations in salmon reproduction in the Russian Far East. Proceedings of 1st International Conference on Wood in World Rivers, Corvallis, Oregon State University, 72-73.

SHIELDS F.D., SMITH R.H., 1992. Effects of large woody debris removal on physical characteristics of a sand-bed river. Aquat. Cons.: Mar. Freshwater Ecosyst., 2, 145-163.

SHIRVELL C.S., 1989. Habitat models and their predictive capability to infer habitat effects on stock size. In : LEVINGS C.D., HOLTBY L.B., HENDERSON M.A. (Eds.), Proceedings of the National Workshop on Effects of Habitat Alteration on Salmonid Stocks. Can. Spec. Publ. Fish. Aquat. Sci., 105, 173-179.

SHIRVELL C.S., 1990. Role of instream rootwads as juvenile coho salmon (Onchorhynchus kisutch) and steelhead trout (O. mykiss) cover habitat under varying streamflows. Can. J. Fish. Aquat. Sci., 47, 852-861.

SHULER S.W., NEHRING R.B., FAUSCH K.D., 1994. Diel habitat selection by brown trout in the Rio Grande River, Colorado, after placement of boulder structures. N. Am. J. Fish. Manage., 14, 99-111.

SIH A., ENGLUND G., WOOSTER D., 1998. Emergent impacts of multiple predators on prey. Tree, 13, 350-355.

SIMPKINS D.G., HUBERT W.A., WESCHE T.A., 2000. Effects of fall-to-winter changes in habitat and frazil ice on the movements and habitat use of juvenile rainbow trout in a Wyoming tailwater. Trans. Am. Fish. Soc., 129, 101-118.

SLANEY P.A., RUBLEE B.O., PERRIN C.J., GOLDBERG H., 1994. Debris structure placements and whole-river fertilization for salmonids in a large regulated stream in British Columbia. Bull. Mar. Sci., 55, 1160-1180. 
SMITH R.W., GRIFFITH J.S., 1994. Survival of rainbow trout during their first winter in the Henrys Fork of the Snake River, Idaho. Trans. Am. Fish. Soc., 123, 747-756.

SMOCK L.A., METZLER G.M., GLADDEN J.E., 1989. The role of debris dams in the structure and functioning of low gradient headwater streams. Ecology, 70, 764-775.

SOLAZZI M.F., NICKELSON T.E., JOHNSON S.L., RODGERS J.D., 2000. Effects of increasing winter rearing habitat on abundance of salmonids in two coastal Oregon streams. Can. J. Fish. Aquat. Sci., 57, 906-914.

SPALDING S., PETERSON N.P., QUINN T.P., 1995. Summer distribution, survival, and growth of juvenile coho salmon under varying experimental conditions of brushy instream cover. Trans. Am. Fish. Soc., 124, 124-130.

STEVENSON N.J., BAIN M.B., 1999. Cover and refuge. In : BAIN M.B., STEVENSON N.J. (Eds.), Aquatic habitat assessment: common methods. American Fisheries Society, Bethesda, Maryland, 105-113.

STONEMAN C.L., JONES M.L., 2000. The influence of habitat features on the biomass and distribution of three species of southern Ontario stream salmonines. Trans. Am. Fish. Soc., 129, 639-657.

STREUBEL D.N., GRIFFITH J.S., 1993. Use of boulder pocket habitat by rainbow trout (Oncorhynchus mykiss) in Fall River, Idaho. Great Basin Nat., 53, 194-198.

SUNDBAUM K., NÄSLUND I., 1998. Effects of woody debris on the growth and behaviour of brown trout in experimental stream channels. Can. J. Zool., 76, 56-61.

SUREN A.M., WINTERBOURN M.J., 1992. The influence of periphyton, detritus and shelter on invertebrate colonization of aquatic bryophytes. Freshwater Biol., 27, 327-340.

SWALES S., O'HARA K., 1980. Instream habitat improvement devices and their use in freshwater fisheries management. J. Environ. Manage., 10, 167-179.

SWALES S., O'HARA K., 1983. A short-term study of the effects of a habitat improvement programme on the distribution and abundance of fish stocks in a small lowland river in Shropshire. Fish. Manage., 14, 135-144.

THÉVENET A., 1998. Intérêt des débris ligneux grossiers pour les poissons dans les grandes rivières. Pour une prise en compte de leur dimension écologique dans la gestion des cours d'eau. Ph. D Thesis, Lyon 1 University, France.

THUROW R.F., 1997. Habitat utilization and diel behavior of juvenile bull trout (Salvelinus confluentus) at the onset of winter. Ecol. Freshwater Fish, 6, 1-7.

TODD B.L., RABENI C.F., 1989. Movement and habitat use by stream-dwelling smallmouth bass. Trans. Am. Fish. Soc., 118, 229-242.

TSCHAPLINSKI P.J., HARTMAN G.F., 1983. Winter distribution of juvenile coho salmon (Oncorhynchus kisutch) before and after logging in Carnation Creek, British Columbia, and some implications for overwinter survival. Can. J. Fish. Aquat. Sci., 40, 452-461.

VALDIMARSSON S.K., METCALFE N.B., 1998. Shelter selection in juvenile Atlantic salmon, or why do salmon seek shelter in winter? J. Fish Biol., 52, 42-49.

VALDIMARSSON S.K., METCALFE N.B., SKULASON S., 2000. Experimental demonstration of differences in sheltering behaviour between Icelandic populations of Atlantic salmon (Salmo salar) and Arctic char (Salvelinus alpinus). Can. J. Fish. Aquat. Sci., 57, 719-724.

VALENTIN S., SEMPESKI P., SOUCHON Y., GAUDIN P., 1994. Short-term habitat use by young grayling. Thymallus thymallus L., under variable flow conditions in an experimental stream. Fish. Manage. Ecol., 1, 57-65.

VEHANEN T., BJERKE P.L., HEGGENES J., HUUSKO A., MÄKI-PETÄYS A., 2000. Effect of fluctuating flow and temperature on cover type selection and behaviour by juvenile brown trout in artificial flumes. J. Fish Biol., 56, 923-937.

VILA-GISPERT A., ZAMORA L., MORENO-AMICH R., 2000. Use of the condition of Mediterranean barbel (Barbus meridionalis) to assess habitat quality in stream ecosystems. Arch. Hydrobiol., 148, 135-145.

WAGNER E.J., BOSAKOWSKI T., 1994. Performance and behavior of rainbow trout reared in covered raceways. Prog. Fish-Cult., 56, 123-129. 
WERNER E.E., GILLIAM J.F., HALL D.J., MITTELBACH G.G., 1983a. An experimental test of the effects of predation risk on habitat use in fish. Ecology, 64, 1540-1548.

WERNER E.E., MITTELBACH G.G., HALL D.J., GILLIAM J.F., 1983b. Experimental tests of optimal habitat use in fish: the role of relative habitat profitability. Ecology, 64, 1525-1539.

WESCHE T.A., GOERTLER C.M., FRYE C.B., 1987. Contribution of riparian vegetation to trout cover in small streams. N. Am. J. Fish. Manage., 7, 151-153.

WHITE J.L., HARVEY B.C., 2001. Effects of an introduced piscivorous fish on native benthic fishes in a coastal river. Freshwater Biol., 46, 987-995.

WILZBACH M.A., 1985. Relative roles of food abundance and cover in determining the habitat distribution of stream-dwelling cutthroat trout (Salmo clarki). Can. J. Fish. Aquat. Sci., 42, 1668-1672.

WILZBACH M.A., CUMMINS K.W., HALL J.D., 1986. Influence of habitat manipulations on interactions between cutthroat trout and invertebrate drift. Ecology, 67, 898-911.

YOUNG M.K., 1995. Telemetry-determined diurnal positions of brown trout (Salmo trutta) in two South-central Wyoming streams. Am. Midl. Nat., 133, 264-273. 